\title{
Corrosion Inhibiting Mechanism of Nitrite Ion on the Passivation of Carbon Steel and Ductile Cast Iron for Nuclear Power Plants
}

\author{
K. T. Kim, ${ }^{1}$ H. W. Kim, ${ }^{1}$ H. Y. Chang, ${ }^{2}$ B. T. Lim, ${ }^{2}$ H. B. Park, ${ }^{2}$ and Y. S. Kim ${ }^{1}$ \\ ${ }^{1}$ Materials Research Centre for Energy and Clean Technology, School of Materials Science and Engineering, \\ Andong National University, 1375 Gyeongdongro, Andong 760-749, Republic of Korea \\ ${ }^{2}$ Power Engineering Research Institute, KEPCO Engineering \& Construction Company, 8 Gumiro, Bundang, Seongnam, \\ Gyeonggi 463-870, Republic of Korea \\ Correspondence should be addressed to Y. S. Kim; yikim@anu.ac.kr
}

Received 1 July 2015; Accepted 27 September 2015

Academic Editor: Randhir Singh

Copyright (C) 2015 K. T. Kim et al. This is an open access article distributed under the Creative Commons Attribution License, which permits unrestricted use, distribution, and reproduction in any medium, provided the original work is properly cited.

\begin{abstract}
While $\mathrm{NaNO}_{2}$ addition can greatly inhibit the corrosion of carbon steel and ductile cast iron, in order to improve the similar corrosion resistance, $c a$. 100 times more $\mathrm{NaNO}_{2}$ addition is needed for ductile cast iron compared to carbon steel. A corrosion and inhibition mechanism is proposed whereby $\mathrm{NO}_{2}{ }^{-}$ion is added to oxidize. The $\mathrm{NO}_{2}{ }^{-}$ion can be reduced to nitrogen compounds and these compounds may be absorbed on the surface of graphite. Therefore, since nitrite ion needs to oxidize the surface of matrix and needs to passivate the galvanic corroded area and since it is absorbed on the surface of graphite, a greater amount of corrosion inhibitor needs to be added to ductile cast iron compared to carbon steel. The passive film of carbon steel and ductile cast iron, formed by $\mathrm{NaNO}_{2}$ addition showed $\mathrm{N}$-type semiconductive properties and its resistance, is increased; the passive current density is thus decreased and the corrosion rate is then lowered. In addition, the film is mainly composed of iron oxide due to the oxidation by $\mathrm{NO}_{2}{ }^{-}$ion; however, regardless of the alloys, nitrogen compounds (not nitrite) were detected at the outermost surface but were not incorporated in the inner oxide.
\end{abstract}

\section{Introduction}

Since the operation period of nuclear power plants around the world increases each year, the degradations in buried pipes have become an important issue in the nuclear power industry. Many reports have been carried out on the degradation of buried pipes, such as the lining damage of buried pipe for a component cooling seawater system at Hanul \#1 unit (Korea), 1998 [1], the leakage of buried pipe for a fire protection system at Hanbit \#4 unit (Korea), 2006 [2], and the cooling water leakage $\left(c a .2 .27 \mathrm{~m}^{3}\right)$ at Indian Point \#2 unit (USA), 2009 [3]. In the case of buried pipe, its corrosion environment differs from that of air-exposure pipe. While the interior of the pipe becomes corroded by fluids, the outside undergoes mechanical and chemical damage from the soil. Also, even though leakage occurs in the buried pipe, it is very difficult to determine the reason for the leakage and to fix it timely because of a lack of accessibility. Various pipes of $c a .30 \sim 40 \mathrm{~km}$ per unit of nuclear power plant have been buried and operated, and depending on the application system and water chemistry, they are separately maintained as the large diameter pipes and the other pipes. Large diameter pipes are installed to convey the primary cooling seawater system, the secondary cooling seawater system, and the circulating system, the cooling water of which is seawater $[4,5]$. About $70 \%$ of pipes are Prestressed Concrete steel Cylinder Pipe (PCCP) and Prestressed Concrete Pipe (PCP). Another pipework has been installed for conveying water for the fire-fighting system, which was made of carbon steel or cast iron [6]. The types of damage that can occur in buried pipe include leakage, fracture, blockage, and deformation by mechanical impact. Secondary damage 
TABLE 1: Chemical compositions of experimental alloys.

\begin{tabular}{|c|c|c|c|c|c|c|c|c|c|c|c|}
\hline \multirow{2}{*}{ Alloys } & \multicolumn{11}{|c|}{ Chemical compositions, wt $\%$} \\
\hline & $\mathrm{C}$ & $\mathrm{Mn}$ & $\mathrm{P}$ & S & $\mathrm{Si}$ & $\mathrm{Cr}$ & $\mathrm{Cu}$ & Mo & $\mathrm{Ni}$ & $\mathrm{V}$ & $\mathrm{Fe}$ \\
\hline CS & 0.26 & 0.86 & 0.014 & 0.005 & 0.23 & 0.04 & 0.057 & 0.033 & 0.029 & 0.008 & bal. \\
\hline DCI & 4.01 & 0.17 & 0.022 & 0.026 & 1.53 & - & 0.023 & 0.028 & 0.059 & 0.016 & bal. \\
\hline
\end{tabular}

CS: carbon steel, ASME SA106 Gr.B; DCI: ductile cast iron, KS D4311.

then occurs, including general corrosion, pitting, microbial induced corrosion, scale buildup, multiplication of microbial, and fatigue. Therefore, several corrosion control methods such as painting and coating, electrical protection, and the use of corrosion inhibitors have been applied [7-9]. Carbon steel and cast iron used in a closed cooling system may be corroded. In order to control this type of corrosion problem, corrosion inhibitors such as nitrite, silicate, molybdate, and hydrazine have been used among them; nitrite is widely used because of its excellent performance.

Many reports have been presented on corrosion inhibition by nitrite, including $\mathrm{Fe}_{2} \mathrm{O}_{3}$ formation on steel by nitrite addition [10], adherent protective oxide on steel [11], correlation of oxygen and nitrite on steel corrosion [12], comparative study of nitrite including various inhibitors on steel [13-15], and inhibition effect of nitrite on steel with time $[16,17]$. Nitrite as an anodic inhibitor has a tendency to increase anodic polarization and thus increase corrosion potential to a noble direction and decrease the corrosion current. Since nitrite contains a strong oxidizing power, it oxidizes the surface and forms $\mathrm{Fe}_{2} \mathrm{O}_{3}$ [18]. Formation rate of protective film due to nitrite is very fast and thus among the several corrosion inhibitors, nitrite shows good performance [19].

On the other hand, ductile cast iron has a very different microstructure to that of carbon steel. Spheroidized graphite forms in the matrix and galvanic corrosion occurs between the matrix and graphite. Also, cast iron does not have high corrosion resistance to various corrosion environments and it should be protected by a coating. As described above, many reports have been presented on the corrosion inhibition of carbon steel but there are few reports on cast iron. Therefore, in this work, corrosion inhibition effects of nitrite on carbon steel and ductile cast iron for nuclear power plant pipework using chemical and electrochemical methods were evaluated. This work attempts to clarify the corrosion inhibition mechanism between steel and iron by $\mathrm{NaNO}_{2}$ addition.

\section{Experimental Procedure}

2.1. Materials and Corrosion Environments. Commercial carbon steel (ASME SA106 Gr.B) [20] and ductile cast iron (KS D4311) [21] were used in this work, and Table 1 shows the chemical composition of the experimental alloys.

The test solution was simulated primary cooling water used in the nuclear power plant. The standard solution was $1.6 \mathrm{ppm} \mathrm{NaCl}$ and its $\mathrm{pH}$ was modified with $1 \mathrm{~N} \mathrm{NaOH}$ solution and the range of $\mathrm{pH} 9 \pm 0.2$ was controlled. $\mathrm{NaNO}_{2}$ as a corrosion inhibitor was added as a ppm order.

\subsection{Corrosion Tests}

2.2.1. Immersion Corrosion Test. A specimen was cut to a size of $20 \times 20 \times 5 \mathrm{~mm}$ and each surface was ground using \#120 SiC paper. Immersion tests were carried out in a stagnant solution condition (500 mL glass flask) and in a circulating solution, in which test chamber has a dimension of $50 \times 100 \times 50 \mathrm{~cm}$ and the flow rate was $5 \mathrm{~L} / \mathrm{min}$. After the immersion tests, each specimen was cleaned with acetone and alcohol and was then dried; the corrosion rate was then determined.

2.2.2. Electrochemical Tests. Specimens were cut to a size of $20 \times 20 \mathrm{~mm}$ and, after electrical connection, they were epoxy-mounted and the surface was ground using \#600 $\mathrm{SiC}$ paper and coated with epoxy resin, except an area of $1 \mathrm{~cm}^{2}$. A polarization test was performed using a potentiostat (Gamry DC105) and the reference electrode was a saturated calomel electrode and the counter electrode was Pt wire. The test solution was deaerated using nitrogen gas at the rate of $100 \mathrm{~mL} / \mathrm{min}$ for 30 minutes and the scanning rate was $0.33 \mathrm{mV} / \mathrm{sec}$. In order to measure the $\mathrm{AC}$ impedance, the specimens were ground using \#2,000 $\mathrm{SiC}$ paper and then polished using a diamond paste $(3 \mu \mathrm{m})$. The test solution was the same as that of the polarization test. AC impedance measurement was performed using an electrochemical analyzer (Gamry EIS 300). Before measuring, passivation was treated at $+400 \mathrm{mV}$ (SCE) for carbon steel and $0 \mathrm{mV}$ (SCE) for ductile cast iron for 30 minutes. AC impedance was measured at a passivation potential from $10 \mathrm{kHz}$ to $0.01 \mathrm{~Hz}$ and the $\mathrm{AC}$ voltage amplitude was $10 \mathrm{mV}$. Also, a Mott-Schottky plot was prepared to determine the semiconductive properties of the passive film. The specimen preparation was the same as that for AC impedance measurement and the DC amplitude was $10 \mathrm{mV}$ (peak-to-peak) at $1,580 \mathrm{~Hz}$ of the AC frequency [22]. The capacitance was measured at the scan rate of $50 \mathrm{mV} / \mathrm{sec}$ from $+1 \mathrm{~V}(\mathrm{SCE})$ to $-1.5 \mathrm{~V}$ (SCE).

2.2.3. Surface Analysis. X-ray photoelectron spectroscopy (XPS, K-alpha (Thermo VG, UK), Al-K $\alpha(1486.6 \mathrm{eV}, 12 \mathrm{kV}$, $3 \mathrm{~mA})$ ) was analyzed to determine the chemical state of several species of the passive film. The specimen was cut to a size of $20 \times 20 \times 5 \mathrm{~mm}$ and then ground with \#2000 $\mathrm{SiC}$ paper and polished with a $3 \mu \mathrm{m}$ diamond paste; the specimen was finally cleaned with alcohol using an ultrasonic cleaner. Carbon steel and ductile cast iron were passivated by immersion for 24 hours in 1,000 ppm and 100,000 ppm $\mathrm{NaNO}_{2}$, respectively. The depth profile was obtained every 5 seconds by Ar-sputtering. Also, an Electron Probe Micro Analyzer (EPMA, EPMA-1600, $15 \mathrm{KV}$ ) was used to identify the elemental distribution of the passivated surface. Optical 


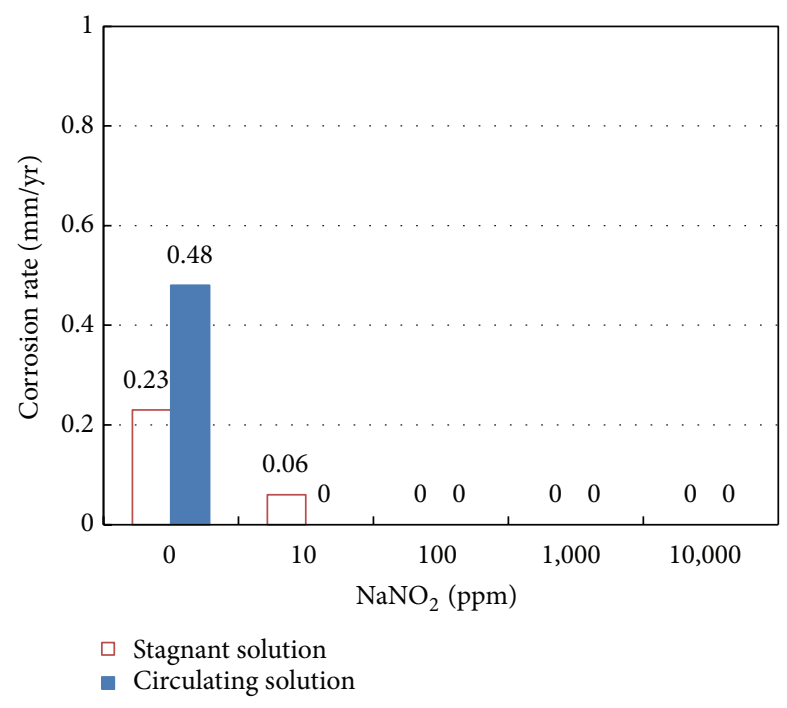

(a)

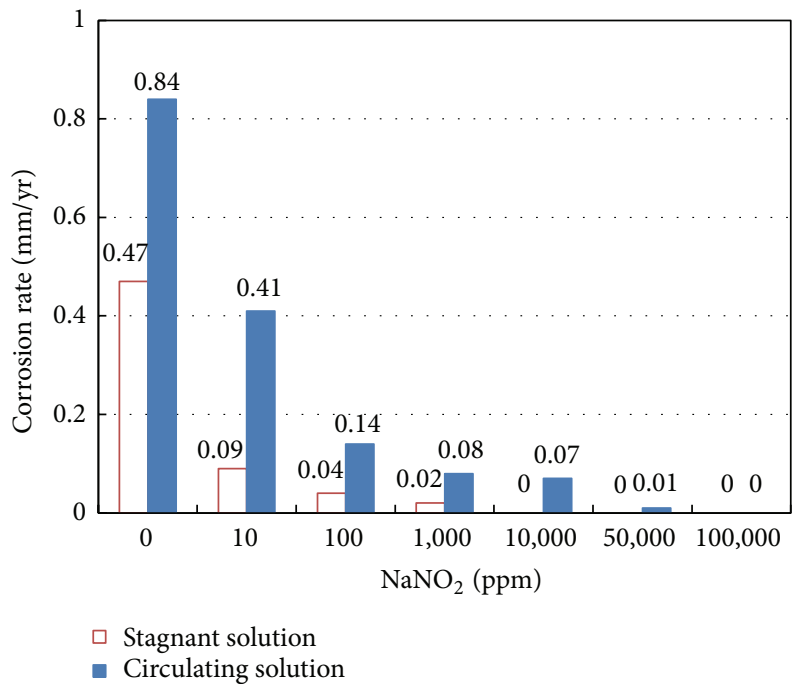

(b)

FIGURE 1: Effect of $\mathrm{NaNO}_{2}$ addition on corrosion rate in circulating and stagnant simulated cooling water at $25^{\circ} \mathrm{C}$; (a) carbon steel and (b) ductile cast iron.

Microscope (OM, Zeiss Axiotech 100HD) and SEM-EDS (Tescan Vega II LMU) and a 3D microscope (Zeiss KH-7700) were used.

2.2.4. Corrosion Simulation. In order to determine the difference in galvanic corrosion between the matrix and spheroidized graphite of the ductile cast iron, computer simulation was performed using COMSOL Multiphysics software. Tafel slopes of anodic and cathodic reactions were used and the rate controlling equation applied in this modeling was the secondary corrosion condition.

\section{Results and Discussion}

3.1. Effect of Nitrite Concentration. Figure 1 shows the effect of $\mathrm{NaNO}_{2}$ addition on corrosion rate in circulating and stagnant simulated cooling water in the air at $25^{\circ} \mathrm{C}$. In the case of carbon steel, increasing $\mathrm{NaNO}_{2}$ concentration reduced significantly the corrosion rate of carbon steel. When the inhibitor was absent, the rates of stagnant and circulating solutions were 0.23 and $0.48 \mathrm{~mm}$ /year, respectively. Also, the effect of nitrite ion was stronger in the circulating solution than in the stagnant solution. However, in the case of ductile cast iron, the effect of nitrite addition was similar to that of carbon steel, but the similar corrosion inhibition of ductile cast iron needs a significant addition of $\mathrm{NaNO}_{2}$. When the inhibitor was absent, the rates of stagnant and circulating solutions were 0.47 and $0.84 \mathrm{~mm} /$ year, respectively. Even though the $\mathrm{NaNO}_{2}$ addition was increased, the corrosion rate of ductile cast iron showed relatively higher values than those of carbon steel. The corrosion of carbon steel can be inhibited at near $100 \mathrm{ppm} \mathrm{NaNO}_{2}$ addition, but the corrosion of ductile cast iron can be inhibited by an addition of more than $10,000 \mathrm{ppm} \mathrm{NaNO}_{2}$. Moreover, while the corrosion of carbon steel can be inhibited more readily by the circulation of the solution, the circulation facilitated the corrosion of ductile cast iron.

The open circuit potential with immersion time by $\mathrm{NaNO}_{2}$ addition in circulating (solid symbol) and stagnant (open symbol) simulated cooling water in the air at $25^{\circ} \mathrm{C}$ was shown in Figure 2. Regardless of the alloys used and the circulation of solution, the open circuit potential of the specimen without $\mathrm{NaNO}_{2}$ addition decreased with immersion time. However, the open circuit potential of the specimen with $\mathrm{NaNO}_{2}$ addition increased and its tendency depends on the alloys. In the case of carbon steel, an addition of $100 \mathrm{ppm} \mathrm{NaNO} \mathrm{N}_{2}$ increased the open circuit potential and the circulation stimulated its rate. Also, in the case of ductile cast iron, a greater concentration (about 100 times) of $\mathrm{NaNO}_{2}$ is needed for a similar effect of $\mathrm{NaNO}_{2}$ addition.

The effect of $\mathrm{NaNO}_{2}$ addition on the polarization behavior in deaerated simulated cooling water at $25^{\circ} \mathrm{C}$ was revealed in Figure 3; the scanning rate was $0.33 \mathrm{mV} / \mathrm{s}$. When $\mathrm{NaNO}_{2}$ is not added, carbon steel and ductile cast iron dissolved readily without the passivation by anodic polarization. With 10 and 100 ppm $\mathrm{NaNO}_{2}$ additions, carbon steel revealed activepassive transition, but the passive current density was high and transpassive behavior occurred. Ductile cast iron did not show an active-passive transition until a 10,000 ppm $\mathrm{NaNO}_{2}$ addition. From a $1,000 \mathrm{ppm} \mathrm{NaNO}_{2}$ addition, carbon steel showed excellent passivation behavior, but the ductile cast iron revealed the best passivation curve from 100,000 ppm $\mathrm{NaNO}_{2}$ addition. This tendency is coincident with the result of the immersion test shown in Figure 1.

Figure 4 shows the corrosion rate due to the $\mathrm{NaNO}_{2}$ addition obtained from the immersion test (circulation condition) shown in Figure 1 and the current density was obtained at $+400 \mathrm{mV}$ (SCE) as shown in Figure 3. Regardless of the chemical or electrochemical tests, the corrosion of carbon steel can be inhibited by a small $\mathrm{NaNO}_{2}$ addition 


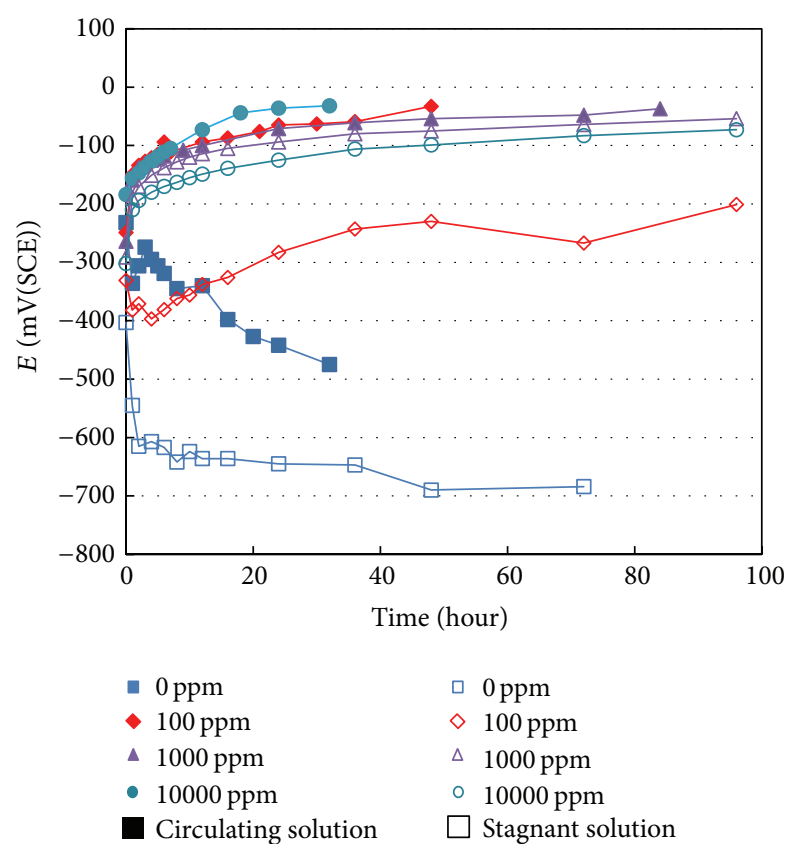

(a)

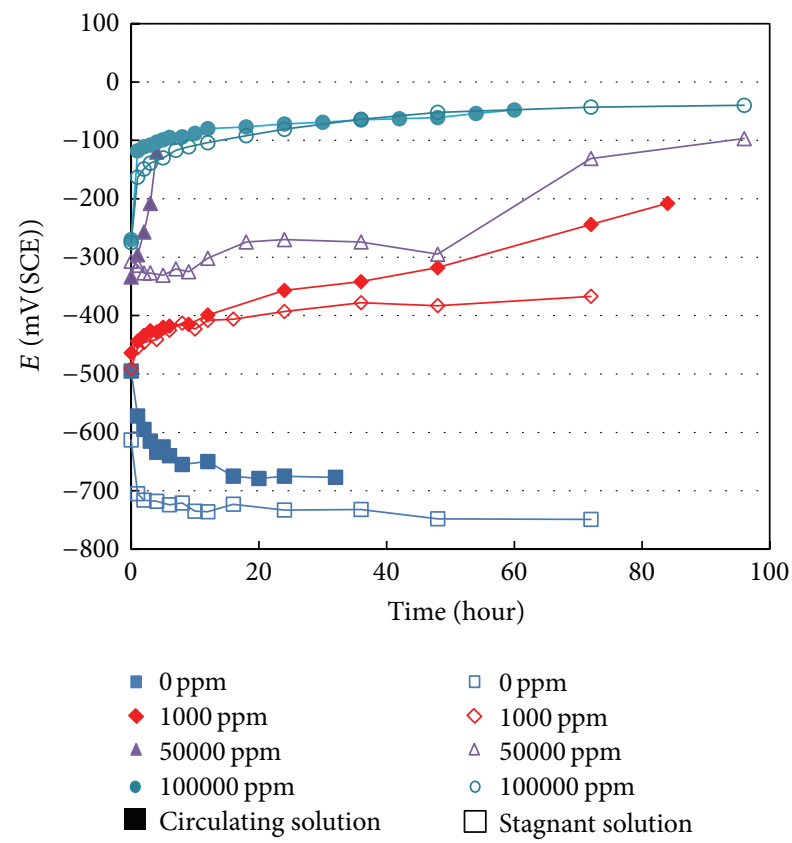

(b)

FIGURE 2: Open circuit potential with immersion time by nitrite addition in circulating (solid symbol) and stagnant (open symbol) simulated cooling water at $25^{\circ} \mathrm{C}$; (a) carbon steel and (b) ductile cast iron.

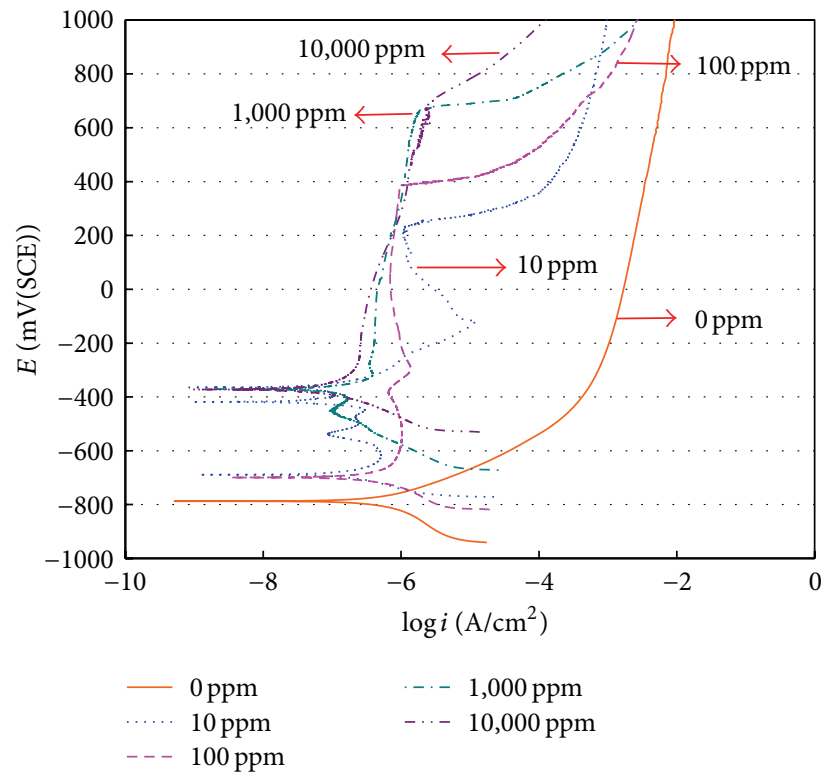

(a)

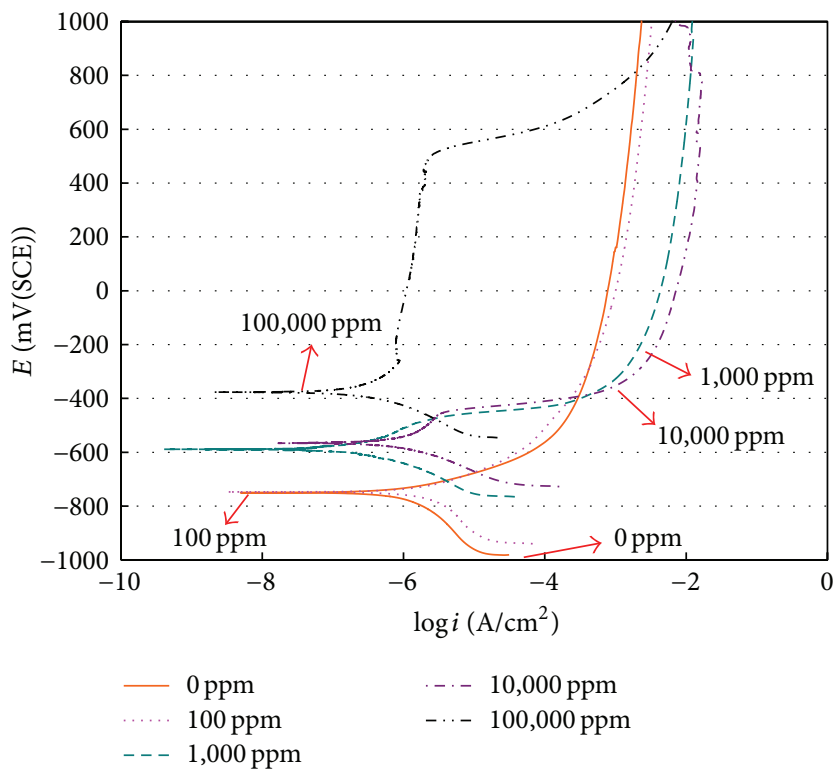

(b)

FIGURE 3: Effect of $\mathrm{NaNO}_{2}$ addition on polarization behavior in deaerated simulated cooling water at $25^{\circ} \mathrm{C}$ (scanning rate; $0.33 \mathrm{mV} / \mathrm{s}$ ); (a) carbon steel and (b) ductile cast iron.

(ca. 1,000 ppm), but the corrosion of ductile cast iron could be only inhibited by a significant $\mathrm{NaNO}_{2}$ addition ( $c a$. $100,000 \mathrm{ppm})$. That is, it was demonstrated that the difference in the $\mathrm{NaNO}_{2}$ addition needed between carbon steel and ductile cast iron was about 100 times.
In order to determine the resistance of the passive film formed on the surface of carbon steel and ductile cast iron by $\mathrm{NaNO}_{2}$ addition, the AC impedance was measured. Figure 5 shows the effect of $\mathrm{NaNO}_{2}$ addition in Nyquist plot obtained from AC impedance measurement at $+400 \mathrm{mV}$ (SCE) for 


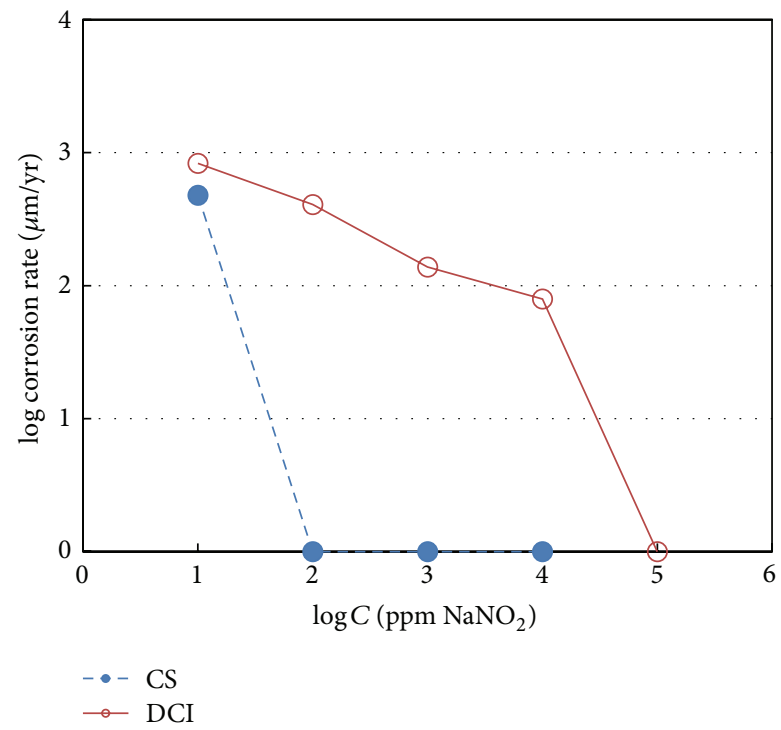

(a)

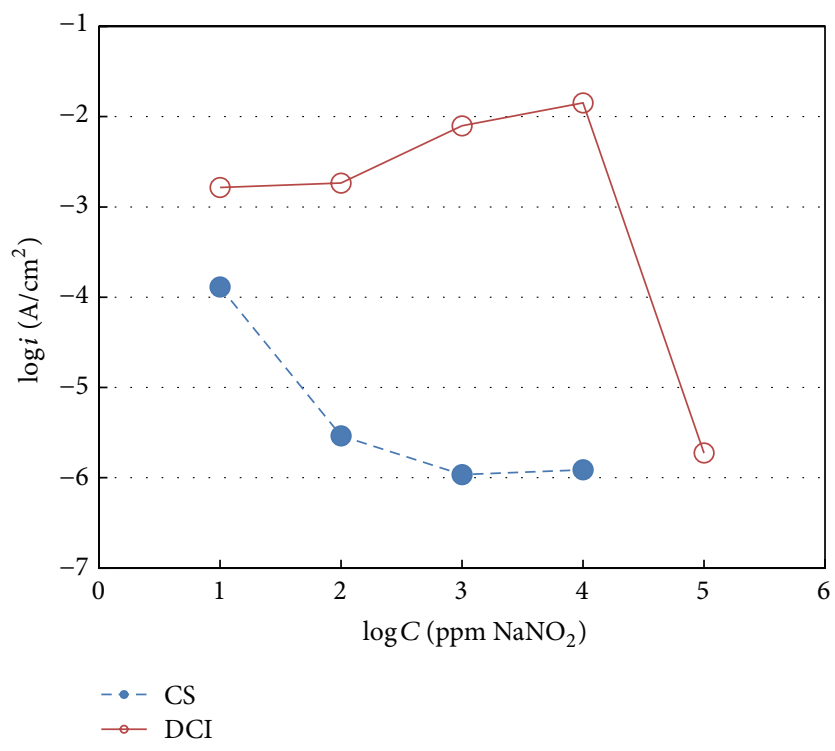

(b)

Figure 4: Comparison of (a) corrosion rate (circulation condition) from Figure 1 and (b) current density obtained at $+400 \mathrm{mV}$ (SCE) of Figure 3 by $\mathrm{NaNO}_{2}$ addition to simulated cooling water.

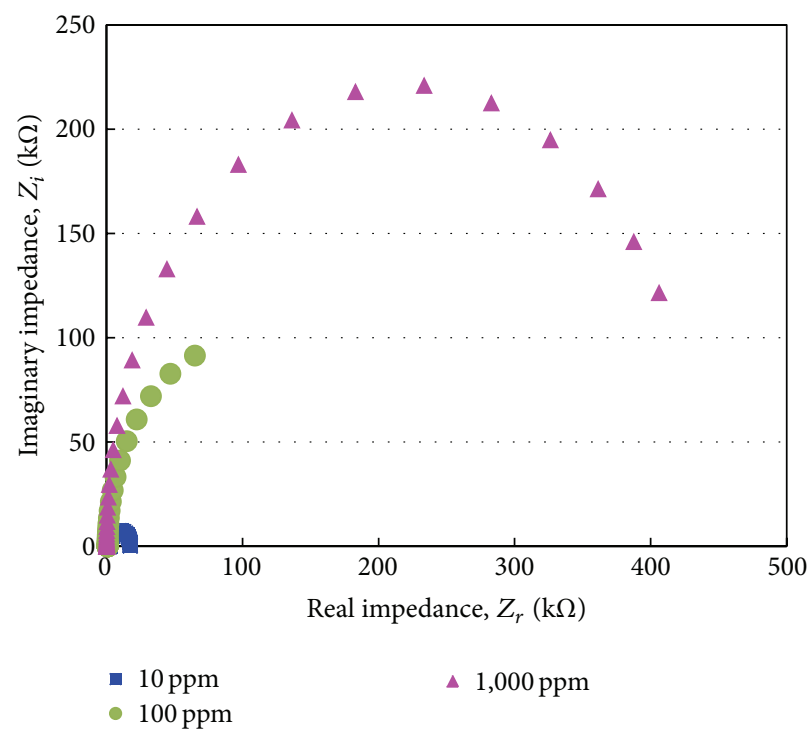

(a)

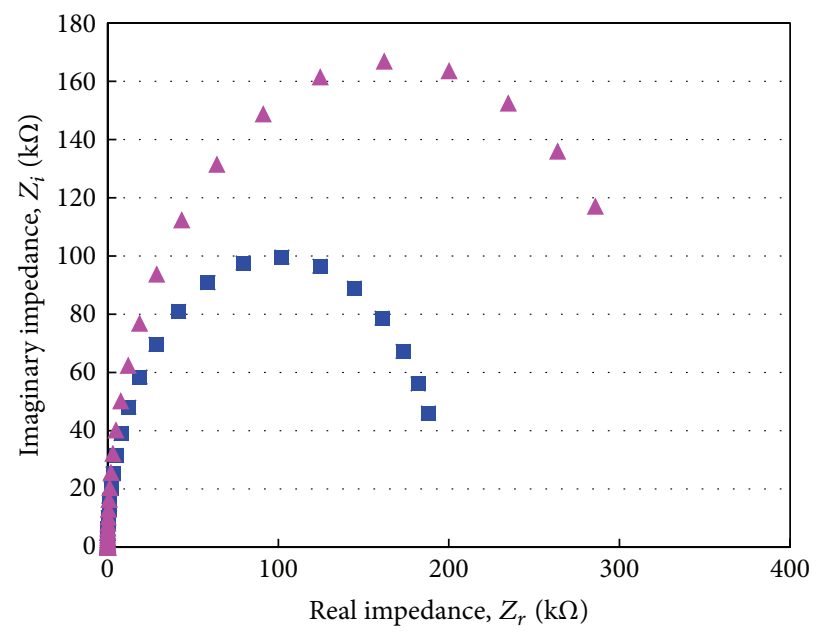

- 50,000 ppm

- $100,000 \mathrm{ppm}$

(b)

FIGURE 5: Effect of $\mathrm{NaNO}_{2}$ addition on Nyquist plot obtained from AC impedance measurement in deaerated simulated cooling water at $25^{\circ} \mathrm{C}$; (a) carbon steel at $+400 \mathrm{mV}$ (SCE) and (b) ductile cast iron at $0 \mathrm{~V}$ (SCE).

carbon steel and $0 \mathrm{~V}$ (SCE) for ductile cast iron in deaerated simulated cooling water at $25^{\circ} \mathrm{C}$. In the case of carbon steel, a stable passive film could not be formed with a $10 \mathrm{ppm} \mathrm{NaNO}_{2}$ addition and very small impedance $(15.6 \mathrm{kohm})$ was thus shown. A 100 ppm $\mathrm{NaNO}_{2}$ addition formed a passive film, but its polarization resistance was small (194.6 kohm). However, a stable passive film (442.5 kohm) was formed with a 1,000 ppm $\mathrm{NaNO}_{2}$ addition. In the case of ductile cast iron, a stable passive film (333.7 kohm) was formed with a 100,000 ppm $\mathrm{NaNO}_{2}$ addition. As shown in Figures 1 and 4, the difference of corrosion inhibition between carbon steel and ductile cast iron due to the $\mathrm{NaNO}_{2}$ addition was closely related to the formation of a stable passive film on the surface.

3.2. Corrosion Inhibition Mechanism of Carbon Steel and Ductile Cast Iron by Nitrite Ion. It was revealed that the difference in the effect of corrosion inhibition due to $\mathrm{NaNO}_{2}$ addition between carbon steel and ductile cast iron was about 100 times through the immersion test and electrochemical tests as described above. As shown in Table 1, the significant 


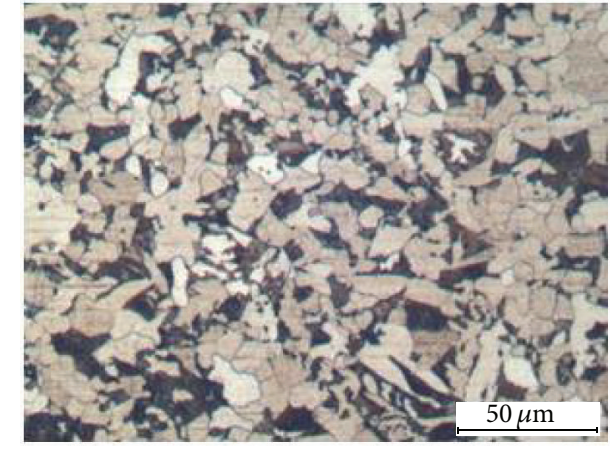

(a)

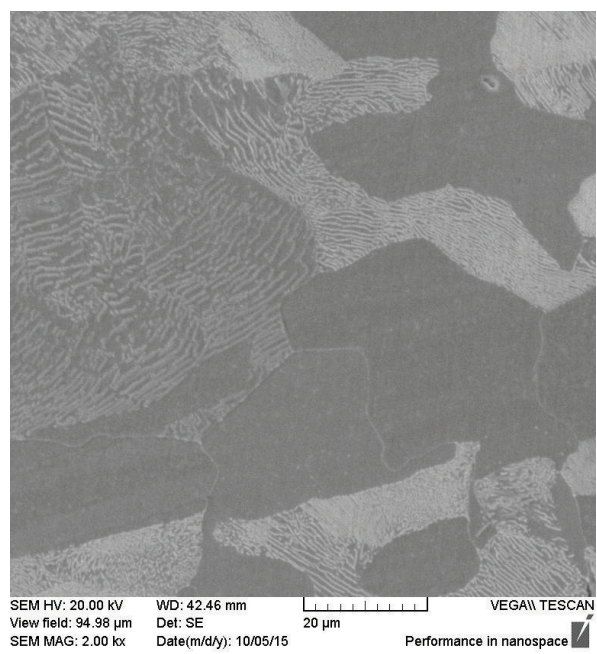

(c)

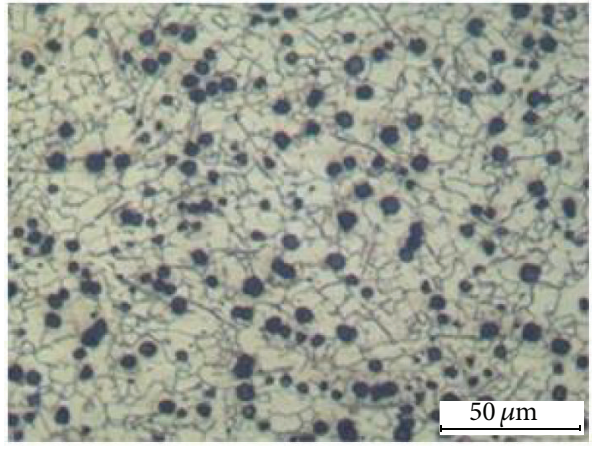

(b)

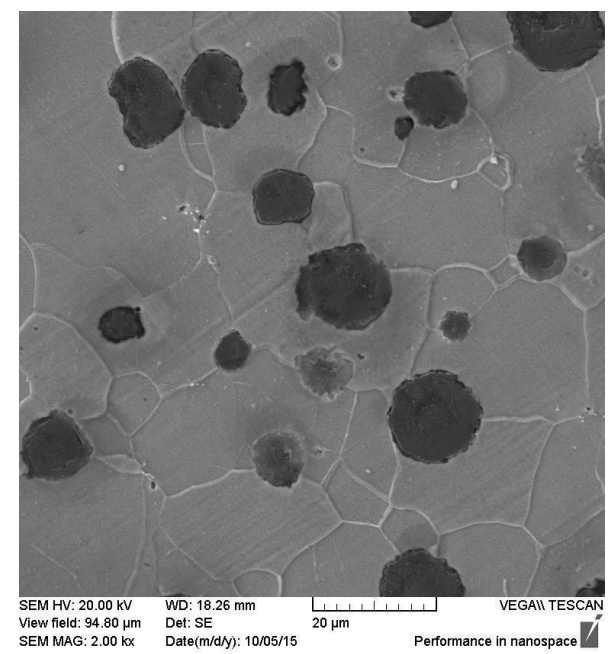

(d)

FIgURE 6: Optical microstructures (a, b) and SEM images (c, d); (a, c) carbon steel and (b, d) ductile cast iron.

difference in the composition between the two alloys is carbon content. Figure 6 shows optical microstructures and SEM images for carbon steel and ductile cast iron. In the case of carbon steel, ferrite and pearlite phases can be observed. However, in the case of ductile cast iron, spheroidized phases were formed in the ferrite matrix and the spheroidized phase was shown to be graphite by SEM-EDS analysis. These pictures show the typical microstructures of carbon steel and ductile cast iron.

In order to determine the effect of $\mathrm{NaNO}_{2}$ addition on the corrosion morphologies of ductile cast iron after immersion, the corroded surface was observed. The effect of $\mathrm{NaNO}_{2}$ addition on the surface appearance of ductile cast iron after the immersion test in simulated cooling water for 3 hours at $25^{\circ} \mathrm{C}$ was presented in Figure 7; Figure 7(a) shows the addition of $0 \mathrm{ppm} \mathrm{NaNO}_{2}$ and Figure 7(b) shows the addition of $10,000 \mathrm{ppm} \mathrm{NaNO}_{2}$. When no $\mathrm{NaNO}_{2}$ was added, the ductile cast iron was generally corroded on the entire surface. However, when 10,000 ppm $\mathrm{NaNO}_{2}$ was added (this addition of which is not sufficient to inhibit corrosion of ductile cast iron as shown in Figures 1 and 3), the iron was corroded locally near the spheroidized graphite and the corroded areas were agglomerated. Figure 8 shows the corrosion morphologies of ductile cast iron in which ductile cast iron was corroded for 3 hours in stagnant simulated cooling water $\left(10,000 \mathrm{ppm} \mathrm{NaNO}_{2}\right)$ at $25^{\circ} \mathrm{C}$. Figure 8 (a) shows the surface contour using a $3 \mathrm{D}$ microscope and local corrosion near the spheroidized graphite was confirmed. Figure 8(b) shows an SEM image of the corroded area, showing that it was corroded spherically near the graphite, and then finally the graphite had chipped off. Also, corrosion products and even cracks were observed near the chipped-off graphite. These figures show that galvanic corrosion took place in the ductile cast iron. It is well known that graphite is nobler than matrix iron [23].

The galvanic corrosion between graphite and matrix iron was simulated using a COMSOL Multiphysics program. Anodic and cathodic Tafel slopes $(+108 \mathrm{mV}$ and $-206 \mathrm{mV}$, resp.) were applied to calculate the corrosion behavior of the corroding and noncorroding areas. Figure 9 shows computer 3D simulation results of the corrosion propagation of ductile cast iron occurring in stagnant simulated cooling water $\left(10,000 \mathrm{ppm} \mathrm{NaNO}_{2}\right)$ at $25^{\circ} \mathrm{C}$. At the initial stage (0 hour), the potential difference between graphite (the center) and matrix (left and right) is shown by the blue and red colors, respectively. By increasing the immersion time, the matrix near the graphite corroded and the corrosion depth was increased; its depth was greater near the graphite. (This is the distance effect observed in galvanic corrosion.) This 


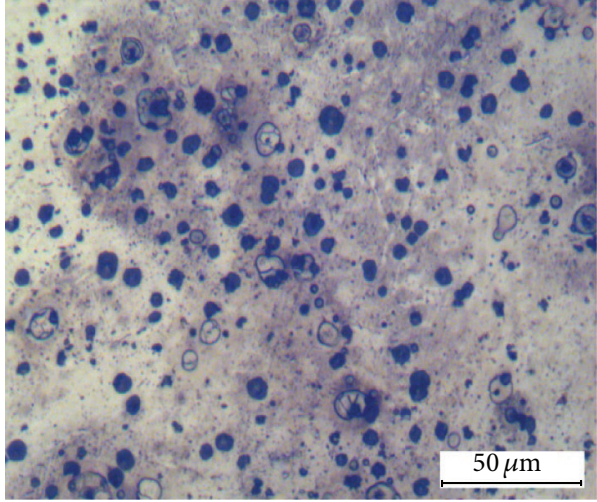

(a)

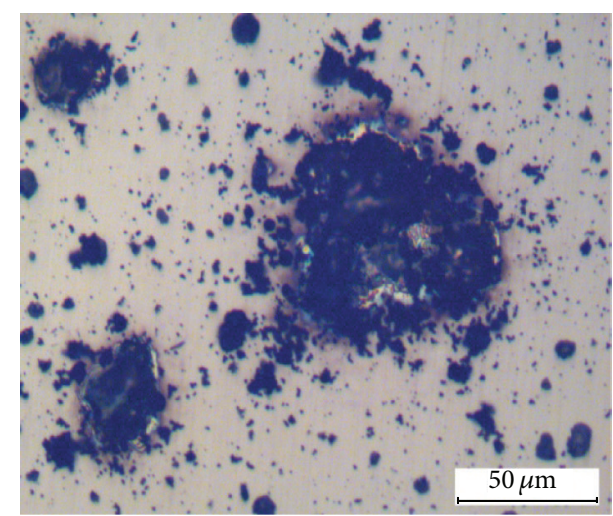

(b)

FigURE 7: Effect of $\mathrm{NaNO}_{2}$ addition on surface appearance of ductile cast iron after the immersion test in simulated cooling water for 3 hours at $25^{\circ} \mathrm{C}$; (a) 0 ppm $\mathrm{NaNO}_{2}$ and (b) $10,000 \mathrm{ppm} \mathrm{NaNO}_{2}$.

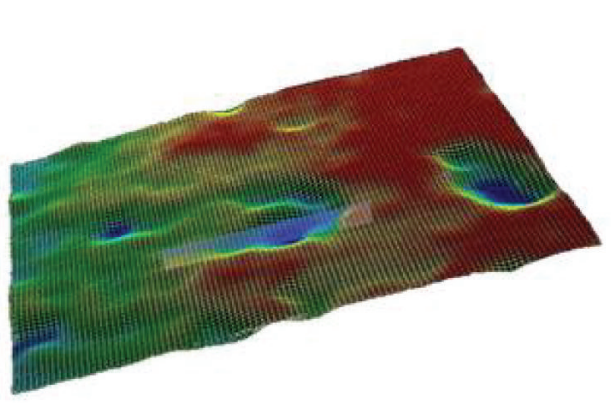

Max: $12.584 \mu \mathrm{m}$

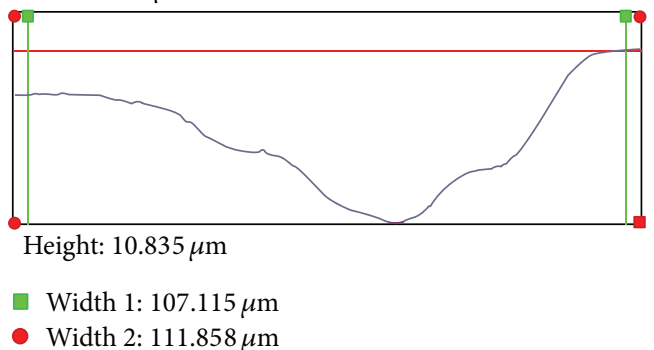

(a)
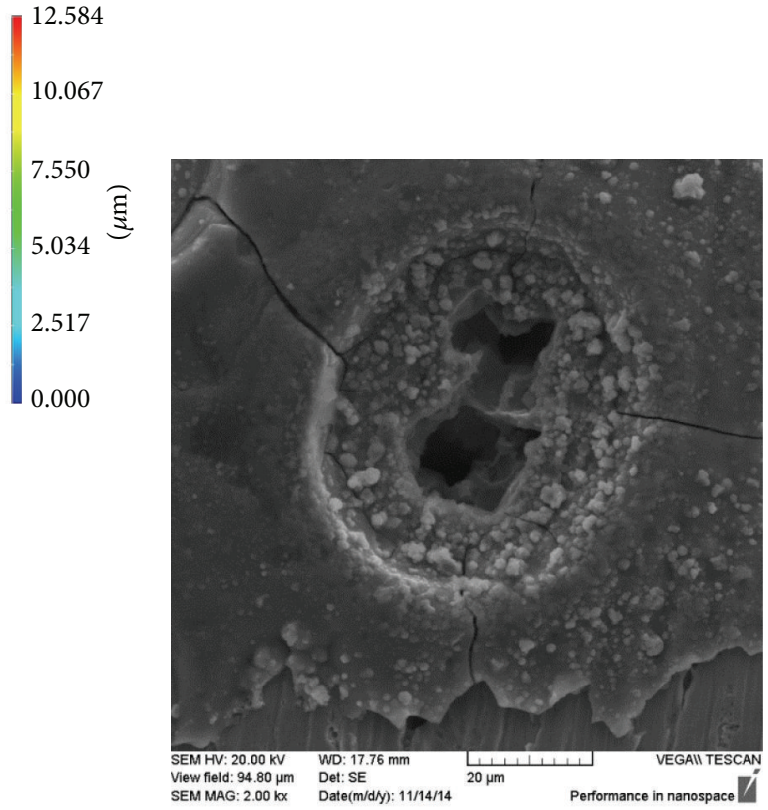

(b)

Figure 8: Corrosion morphologies of ductile cast iron corroded in stagnant simulated cooling water $\left(10,000 \mathrm{ppm} \mathrm{NaNO}_{2}\right)$ for 3 hours at $25^{\circ} \mathrm{C}$; (a) 3D microscope and (b) SEM image.

simulation result differs from that shown in Figure 8(b). This difference could be due to the characteristics of the graphite. (However, it should be noted that the COMSOL Multiphysics program does not simulate the mechanical damage in galvanic corrosion.) The crystal structure of graphite is covalent bonded with neighboring atoms in the same layer, although layers are van der Waals bonded together $[24,25]$ and thus the bonding force of graphite is very weak. Therefore, it is considered that the matrix is corroded galvanically and that the graphite is protruded and then graphite is peeled off layer by layer because of the weak bonding force of graphite.

Figure 10 shows the elemental distribution analyzed using EPMA on the surface of ductile cast iron passivated in simulated cooling water $\left(100,000 \mathrm{ppm} \mathrm{NaNO}_{2}\right)$ at $25^{\circ} \mathrm{C}$ for 72 hours. The SEM image clearly shows the microstructure of ductile cast iron. Fe was depleted in the graphite area and carbon was concentrated as spheroidized shapes. Also, while oxygen was detected on the entire surface, it was particularly concentrated on the graphite area and dim spots of nitrogen were detected. Figure 11 shows the elemental distribution analyzed using EPMA on the surface of ductile cast iron corroded in simulated cooling water $\left(10,000 \mathrm{ppm} \mathrm{NaNO}_{2}\right)$ at $25^{\circ} \mathrm{C}$ for 72 hours. The SEM image shows the locally corroded morphology as seen in Figure 7(b). Fe was not uniform and this is related to local corrosion. However, the carbon distribution was very different to the fully passivated 


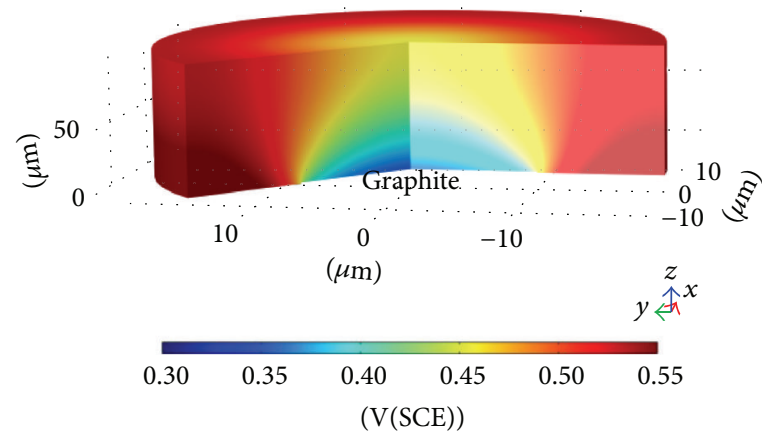

(a)

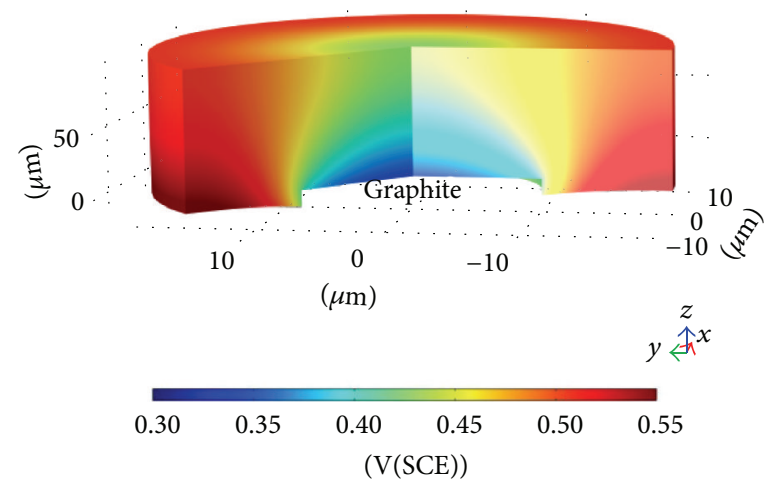

(c)

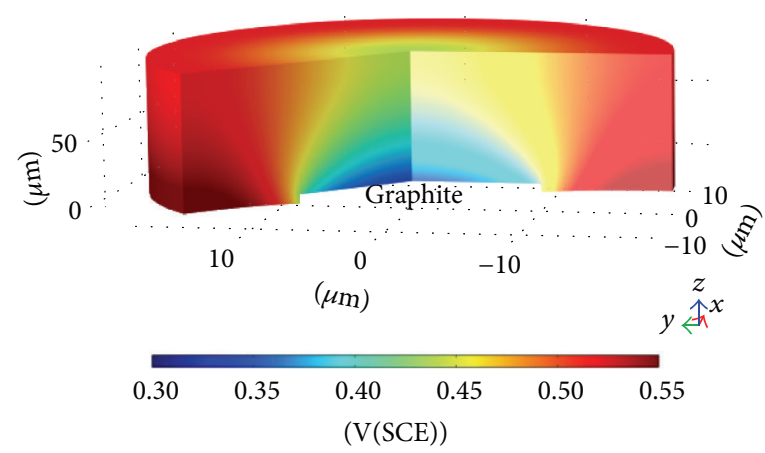

(b)

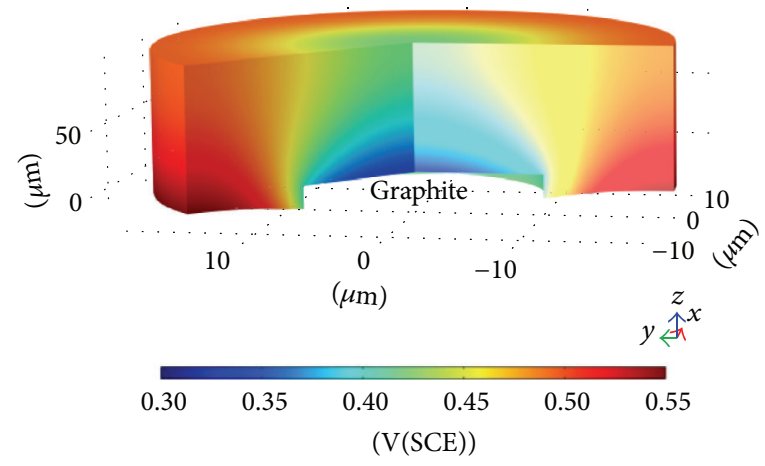

(d)

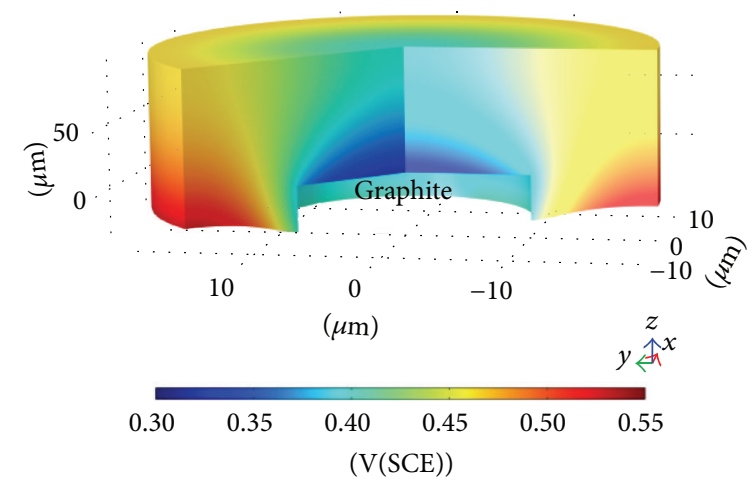

(e)

FIGURE 9: Surface electrolyte potential (V(SCE), the right vertical color bar) obtained by computer 3D simulation (the unit of $x$-, $y$-, and $z$-axes; $\mu \mathrm{m})$ using COSOL Multiphysics on corrosion propagation with immersion time of ductile cast iron occurred in stagnant simulated cooling water $\left(10,000\right.$ ppm $\mathrm{NaNO}_{2}$ ) at $25^{\circ} \mathrm{C}$; (a) 0 hour, (b) 24 hours, (c) 48 hours, (d) 72 hours, and (e) 144 hours.

surface as shown in Figure 10(c). While spheroidized graphite was not observed, destroyed graphite and its location were identified; this result provides the evidence that graphite can be peeled off layer by layer as discussed above. Oxygen was detected more on the Fe-depleted areas and dim spots of nitrogen were detected. This oxygen comes from the sufficient $\mathrm{NaNO}_{2}$. It will be discussed below.

The depth profile on the passivated surface was obtained using XPS to determine the role of nitrite ion on the passivation of steel and iron. Figure 12 shows the depth profile using XPS on the passive film of carbon steel passivated for 24 hours in simulated cooling water $\left(1,000 \mathrm{ppm} \mathrm{NaNO}_{2}\right)$ at $25^{\circ} \mathrm{C}$. Oxygen and nitrogen were enriched at the outer surface and Fe drastically increased with etch time. Figures 12(b) and 12(c) show that iron oxide was enriched at the outer surface. Nitrogen was only detected before sputtering and was not detected at any sputtered depths. This provides evidence that nitrogen is present only on the outermost surface, even with the $\mathrm{NaNO}_{2}$ addition to the solution. Figure 13 shows the depth profile using XPS on the passive film of ductile cast iron passivated for 24 hours in simulated cooling water $\left(100,000 \mathrm{ppm} \mathrm{NaNO}_{2}\right)$ at $25^{\circ} \mathrm{C}$. Oxygen and nitrogen were enriched at the outer surface and $\mathrm{Fe}$ is drastically increased with etch time. Figures 13(b) and 13(c) show that iron oxide 


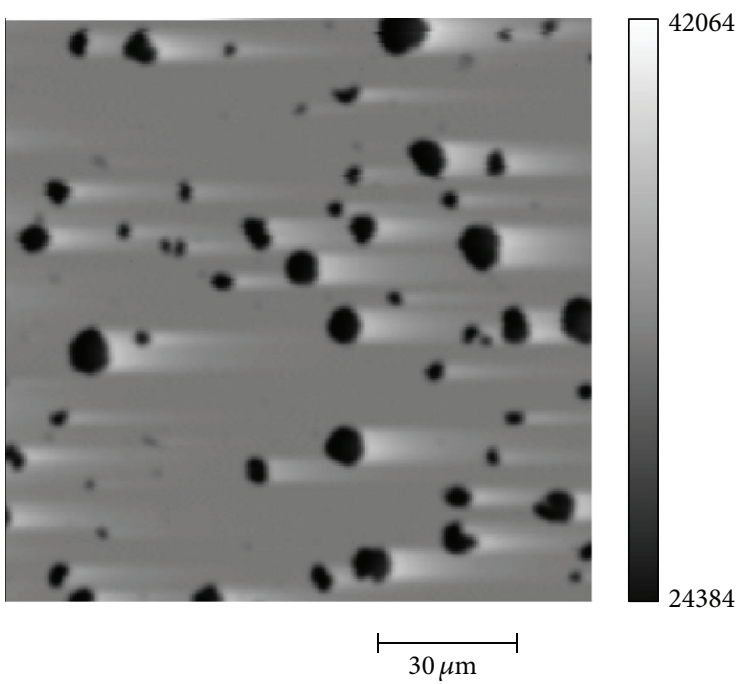

(a)

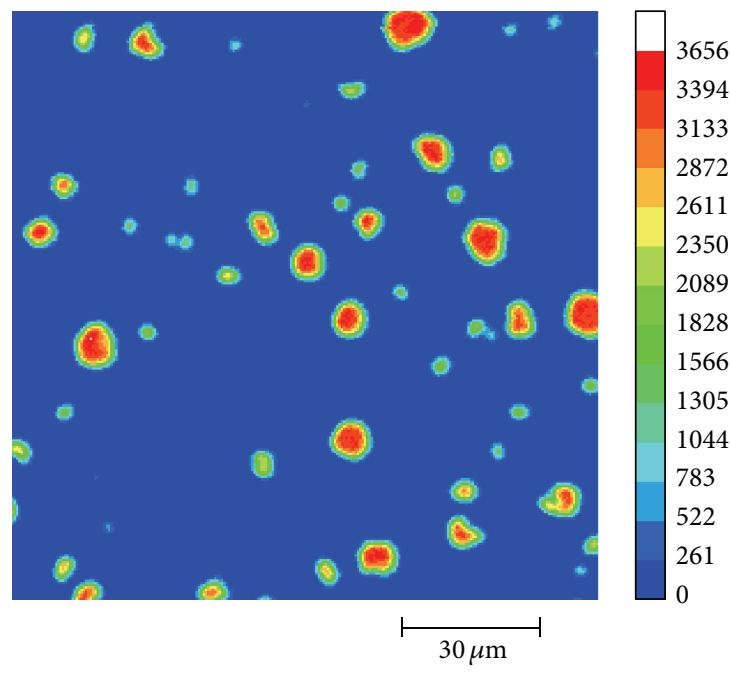

(c)

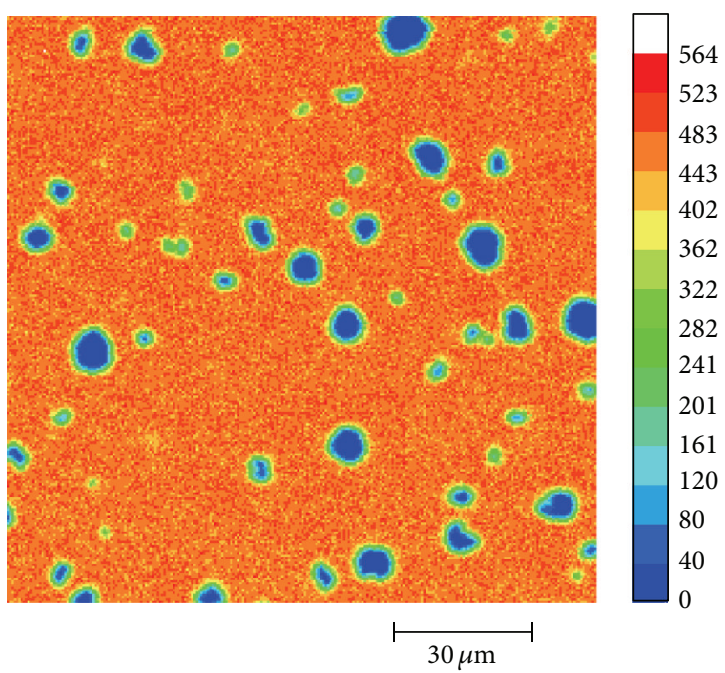

(b)

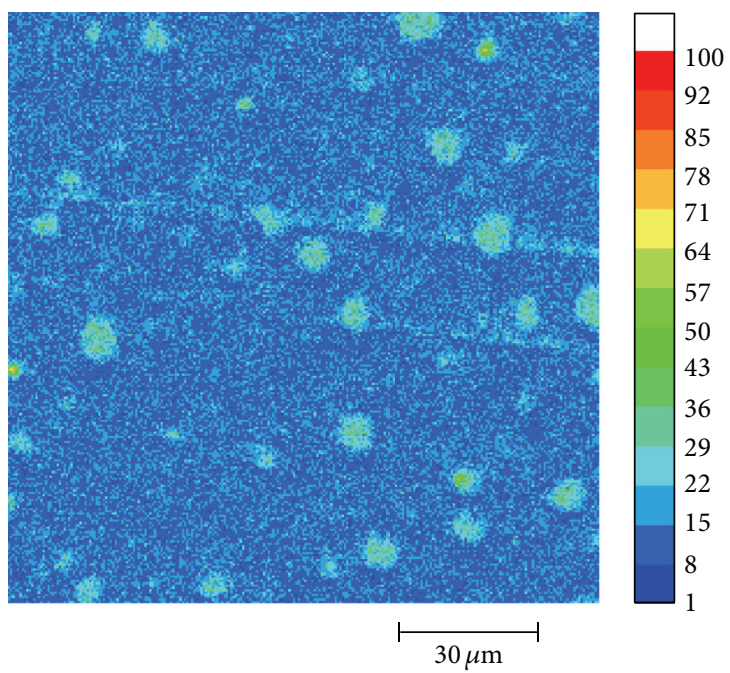

(d)

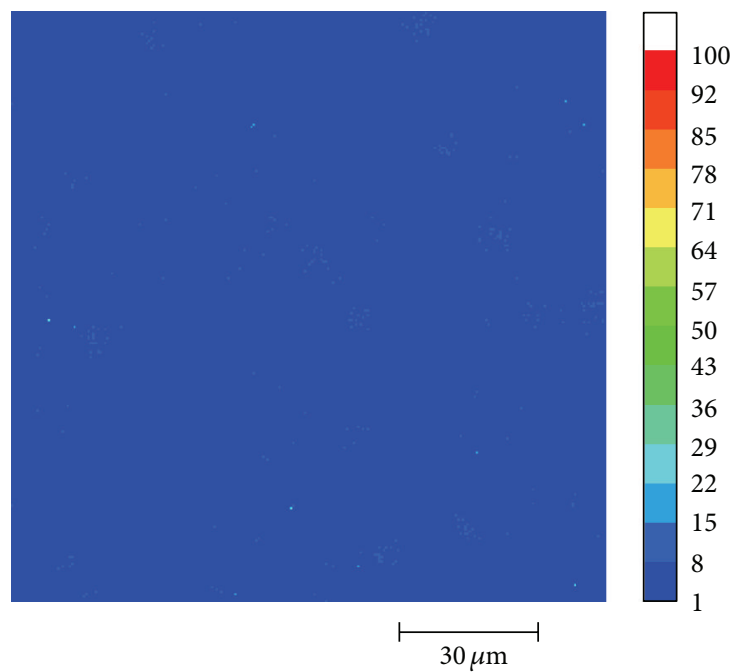

(e)

FIGURE 10: Elemental distribution analyzed by EPMA on the surface of ductile cast iron passivated in simulated cooling water (100,000 ppm $\mathrm{NaNO}_{2}$ ) at $25^{\circ} \mathrm{C}$ for 72 hours; (a) SEM image, (b) Fe, (c) C, (d) O, and (e) $\mathrm{N}$. 


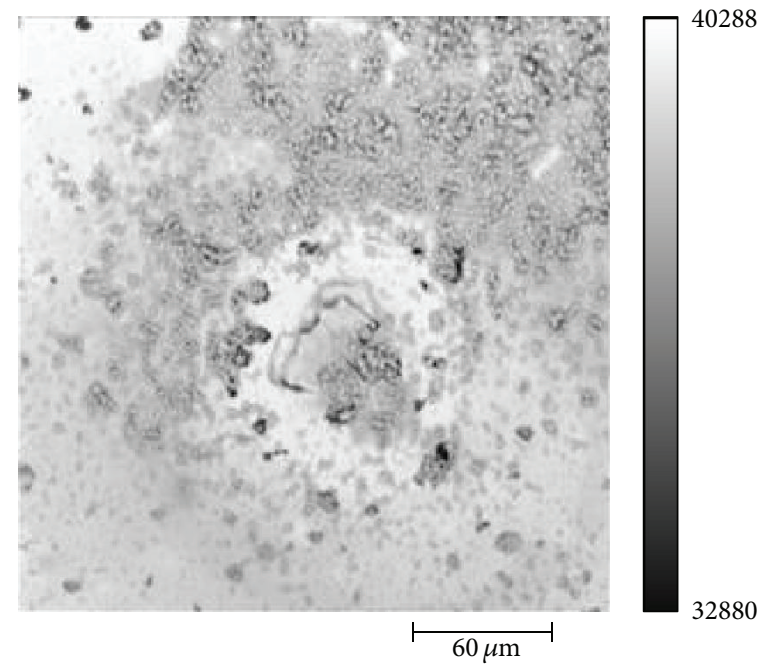

(a)

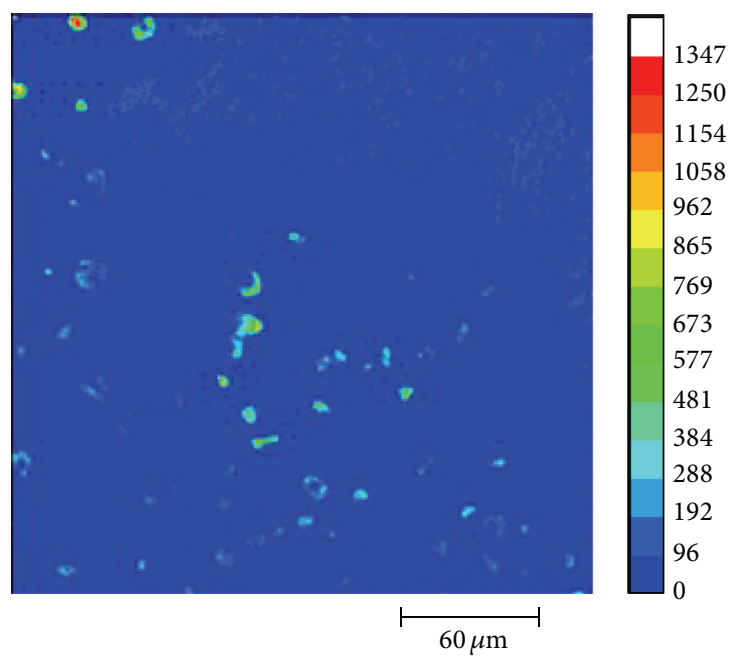

(c)

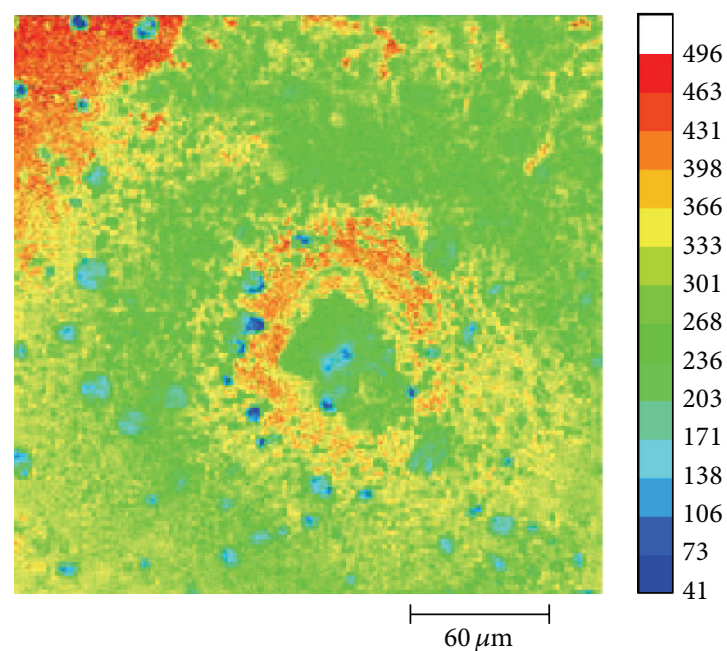

(b)

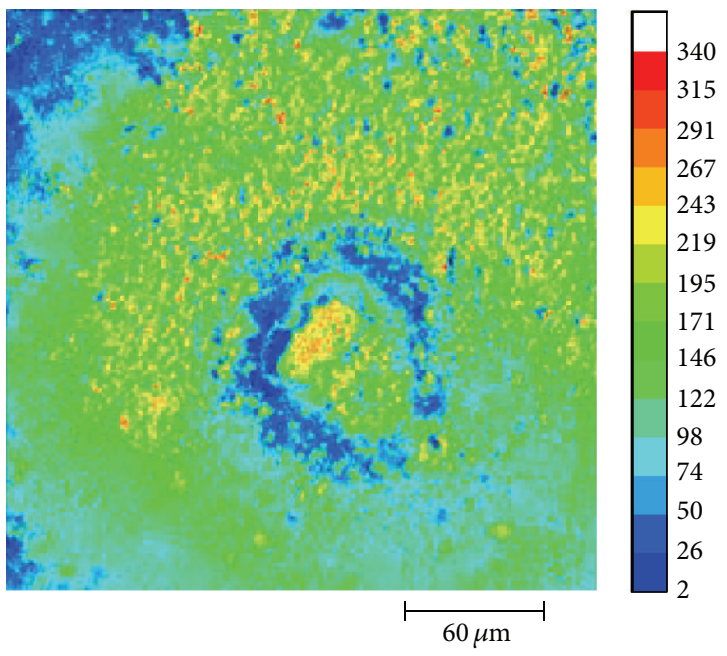

(d)

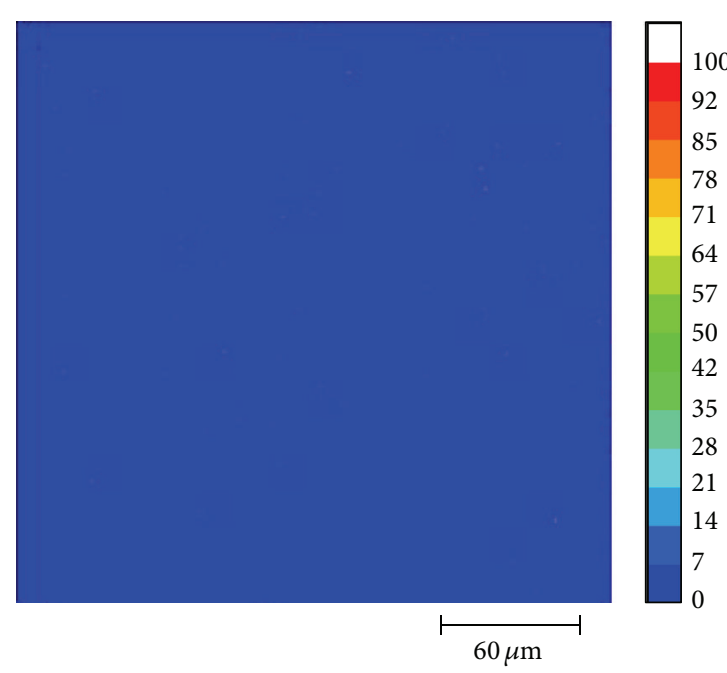

(e)

FIGURE 11: Elemental distribution analyzed by EPMA on the surface of ductile cast iron corroded in simulated cooling water (10,000 ppm $\mathrm{NaNO}_{2}$ ) at $25^{\circ} \mathrm{C}$ for 72 hours; (a) SEM image, (b) Fe, (c) C, (d) O, and (e) $\mathrm{N}$. 


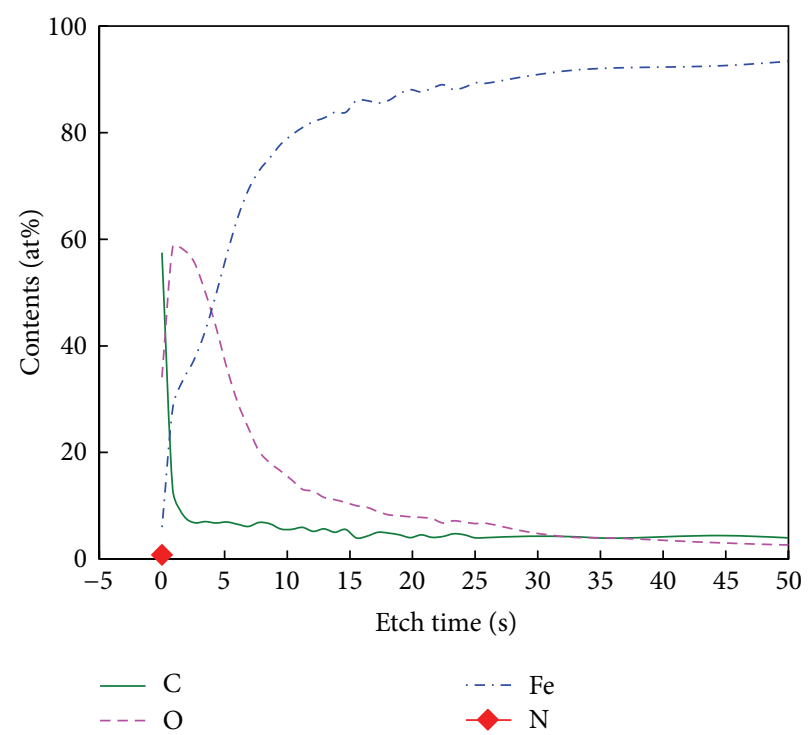

(a)

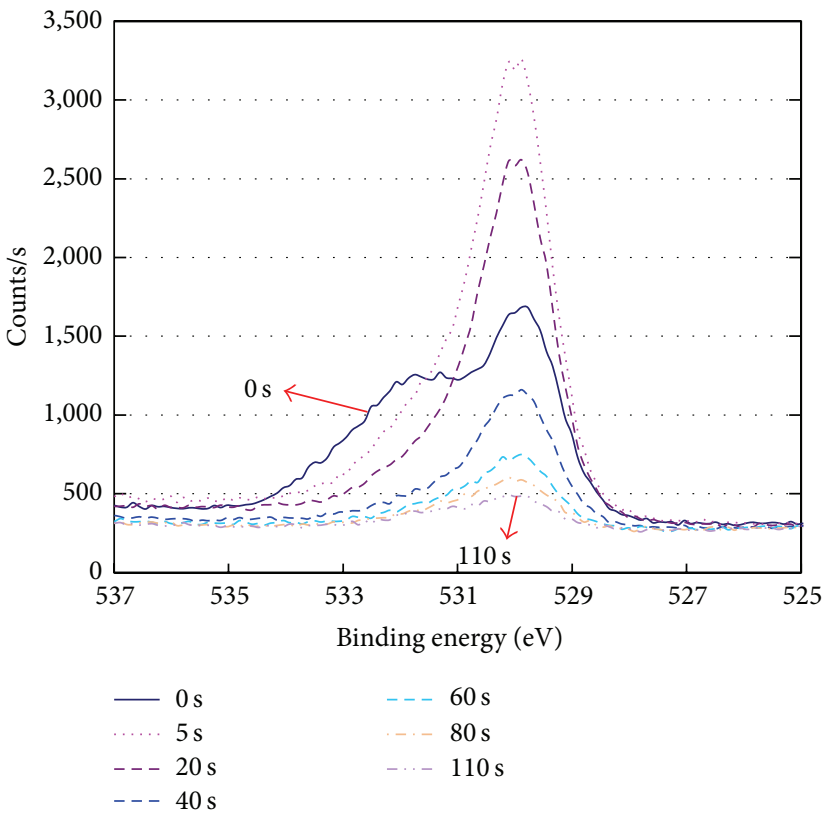

(c)

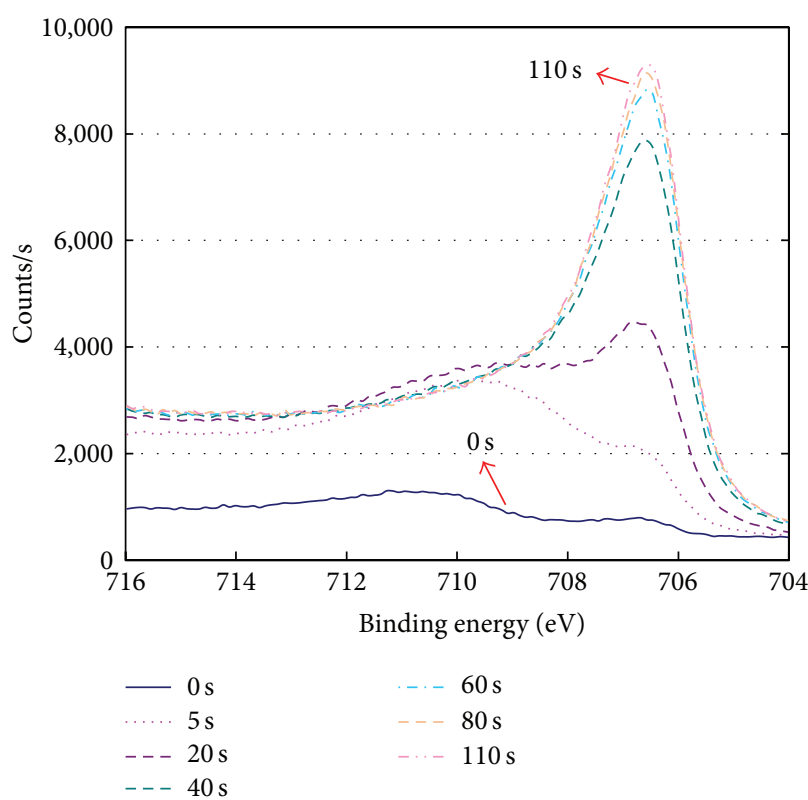

(b)

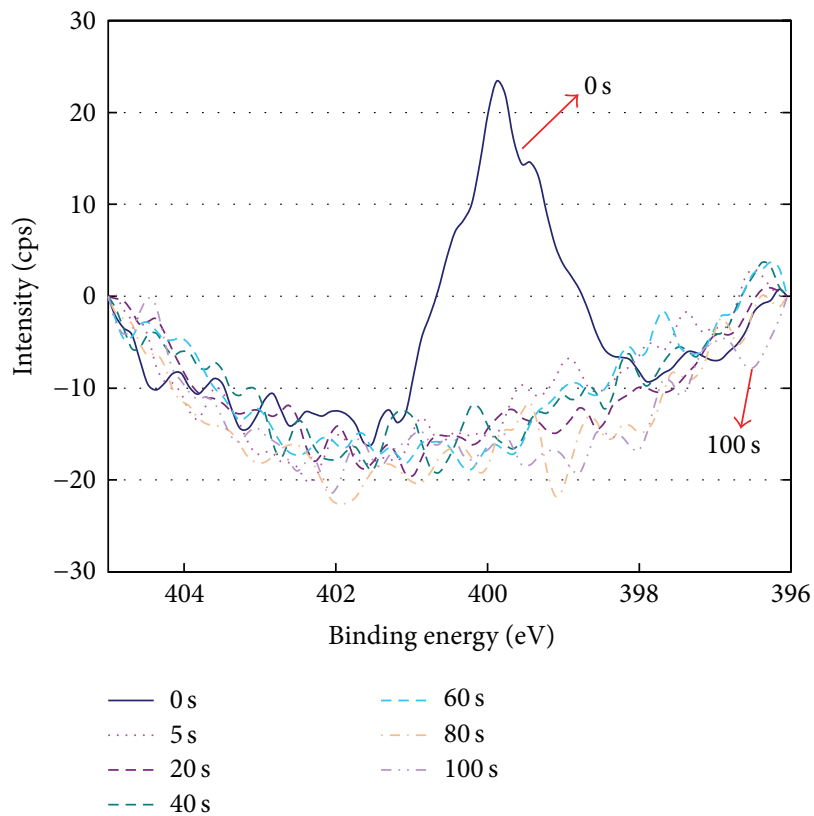

(d)

FIGURE 12: Depth profile by XPS on passive film of carbon steel passivated for 24 hours in simulated cooling water $\left(1,000 \mathrm{ppm} \mathrm{NaNO}_{2}\right)$ at $25^{\circ} \mathrm{C}$; (a) depth profile, (b) $\mathrm{Fe}_{2 \mathrm{p}}$ detail scan, (c) $\mathrm{O}_{1 \mathrm{~s}}$ detail scan, and (d) $\mathrm{N}_{1 \mathrm{~s}}$ detail scan.

was enriched at the outer surface. Nitrogen was only detected before sputtering and at 10 seconds' etch time and was not detected at any sputtered depths. This provides evidence that nitrogen is present only on the outermost surface, even with the $\mathrm{NaNO}_{2}$ addition to the solution. However, nitrogen of passivated ductile cast iron was detected at a slightly deeper depth than that of the passivated carbon steel. This behavior seems to be related to the corrosion and passivation between graphite and matrix in ductile cast iron.
Figure 14 shows the deconvolution of the chemical species determined by XPS on the surface of $(a, b, c)$ carbon steel passivated in $1,000 \mathrm{ppm} \mathrm{NaNO}_{2}$ and $\left(\mathrm{a}^{\prime}, \mathrm{b}^{\prime}, \mathrm{c}^{\prime}\right)$ ductile cast iron passivated in $100,000 \mathrm{ppm} \mathrm{NaNO}_{2}$. Regardless of the alloys and sputtering time $(0 \mathrm{sec}$. and $10 \mathrm{sec}$.), the passive films formed by $\mathrm{NaNO}_{2}$ addition were composed of iron oxides $\left(\mathrm{Fe}^{2+}\right.$ and $\left.\mathrm{Fe}^{3+}\right)$. Also, nitrogen before sputtering exists as nitrogen compounds including $\mathrm{NO}^{-}(400.4,399.2 \mathrm{eV})$, $\mathrm{NH}_{4}{ }^{+}(401.1 \mathrm{eV}), \mathrm{NH}_{3}(398.6,399.8 \mathrm{eV})$, and $\mathrm{NO}(399.6 \mathrm{eV})$ 

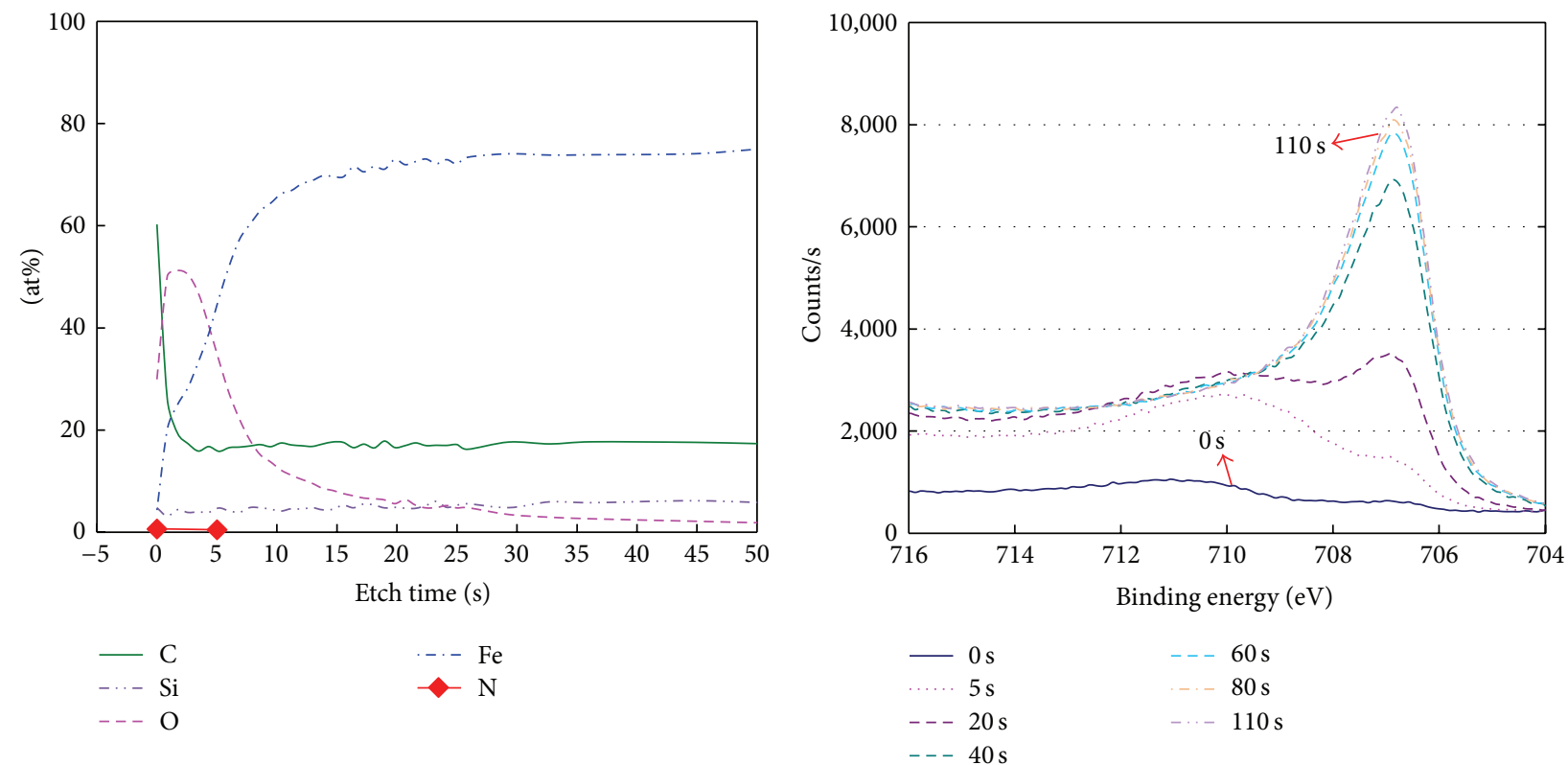

(a)

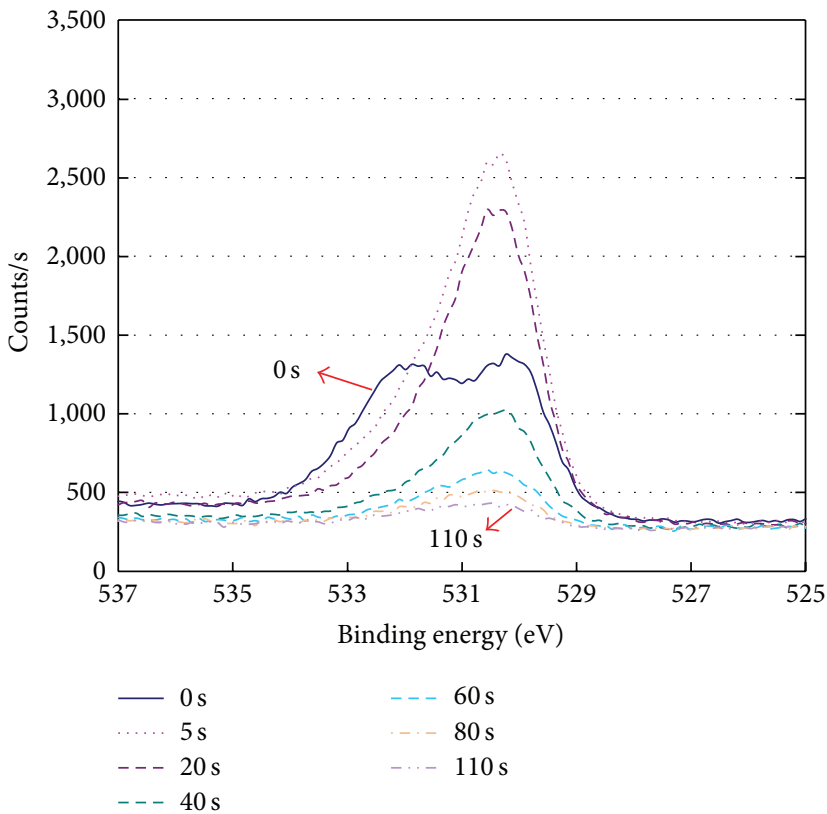

(c)

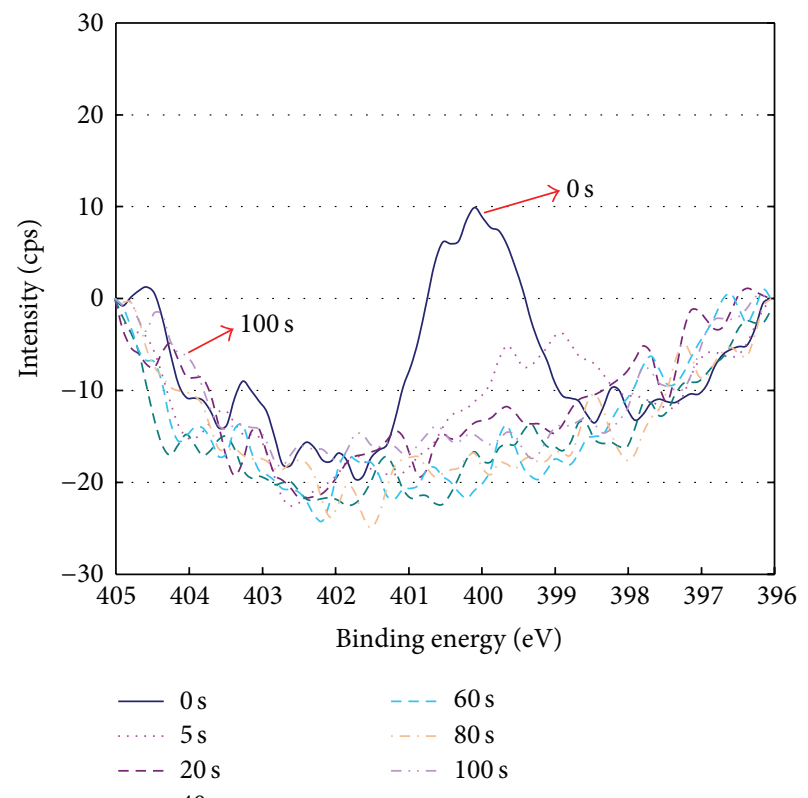

(d)

FIGURE 13: Depth profile by XPS on passive film of ductile cast iron passivated for 24 hours in simulated cooling water $\left(100,000 \mathrm{ppm} \mathrm{NaNO}_{2}\right)$ at $25^{\circ} \mathrm{C}$; (a) depth profile, (b) $\mathrm{Fe}_{2 \mathrm{p}}$ detail scan, (c) $\mathrm{O}_{1 \mathrm{~s}}$ detail scan, and (d) $\mathrm{N}_{1 \mathrm{~s}}$ detail scan.

$[26,27]$. However, it should be noted that the chemical states of nitrogen on the passivated surface are not easy to identify by XPS.

Therefore, as discussed above, corrosion and its inhibition model can be proposed as follows. Figure 15 shows the corrosion and inhibition steps of ductile cast iron with nitrite addition. When no corrosion inhibitor is used, general corrosion and galvanic corrosion occur simultaneously and thus the surface may show relatively uniform corrosion (Figure 15(a)). Also, when the amount of corrosion inhibitor is insufficient (e.g., 10,000 $\mathrm{NaNO}_{2}$ ), some area may be passivated (red line) and galvanic corrosion can occur; finally, the iron then reveals localized corrosion (Figure 15(b)). However, when a sufficient corrosion inhibitor (e.g., 100,000 ppm $\mathrm{NaNO}_{2}$ in Figure 15(c)) is used (even though galvanic corrosion between graphite and matrix has occurred), the entire surface can be passivated and thus corrosion can be inhibited. Also, it should be noted that $\mathrm{NO}_{2}{ }^{-}$ion is used to oxidize the matrix and can itself be reduced to nitric oxide; this compound can be absorbed on the surface of graphite and thus the enriched 


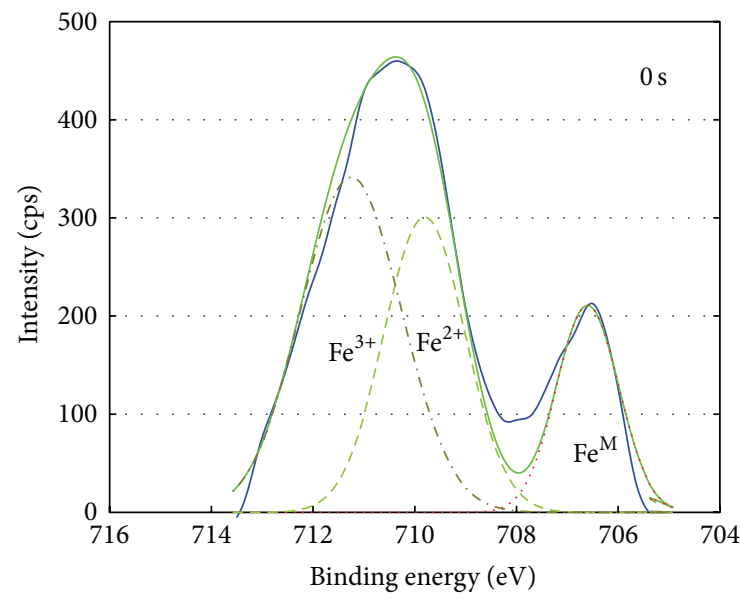

(a)

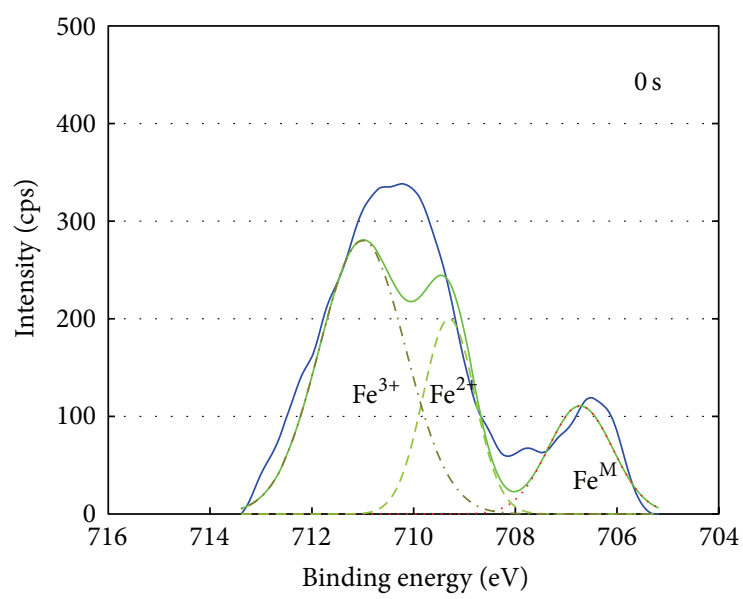

(b)

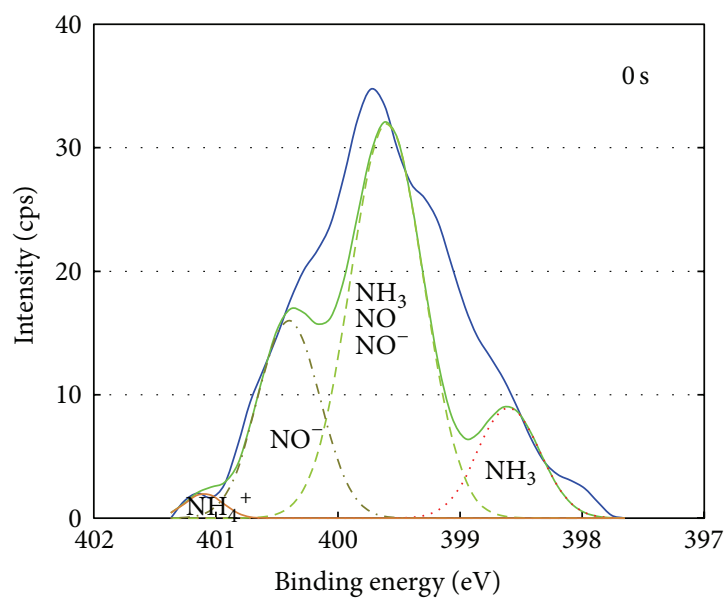

(c)

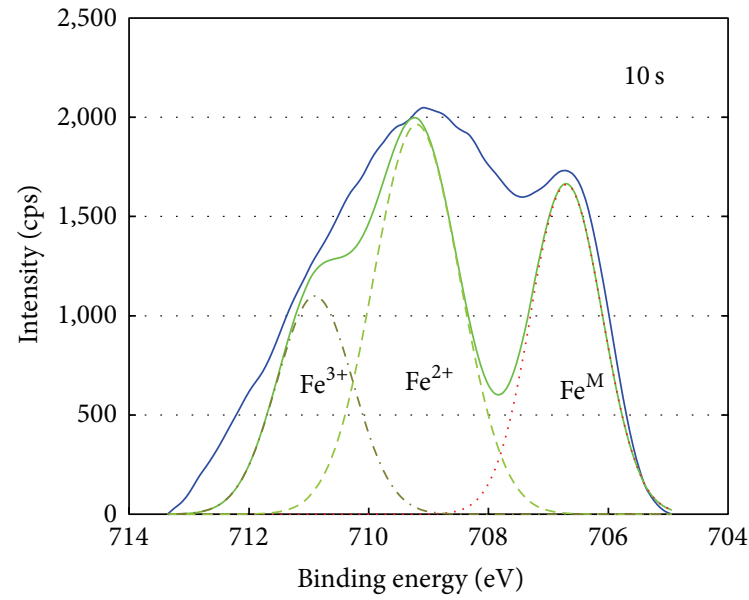

$\left(a^{\prime}\right)$

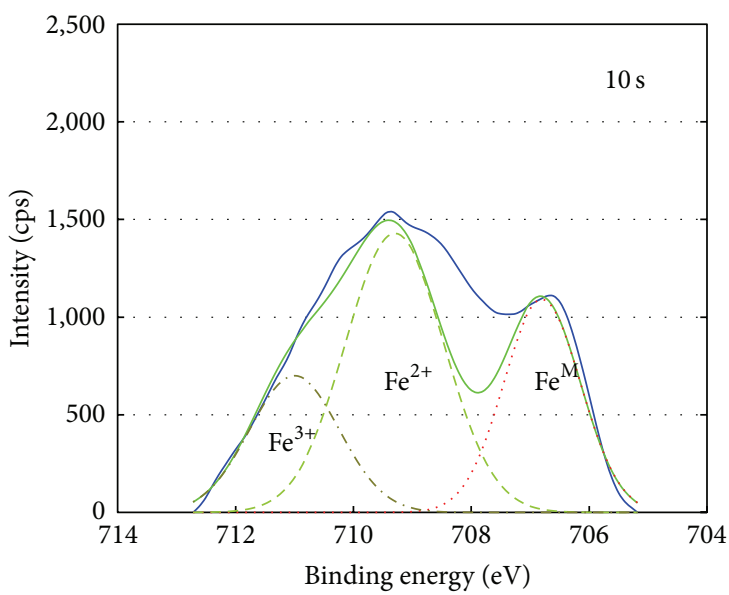

$\left(b^{\prime}\right)$

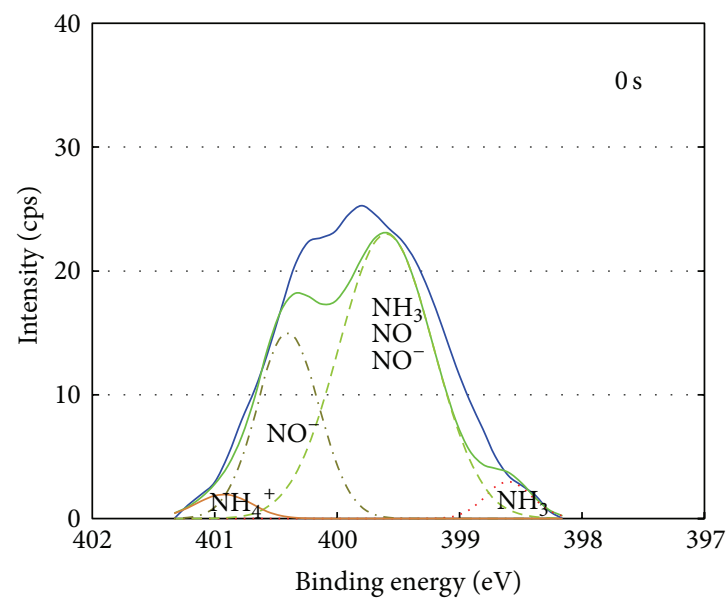

(c')

FIGURE 14: Deconvolution of the chemical species determined by XPS on the surface of $\left(\mathrm{a}, \mathrm{a}^{\prime}, \mathrm{c}\right)$ carbon steel passivated in 1,000 ppm $\mathrm{NaNO}_{2}$ and $\left(b, b^{\prime}, c^{\prime}\right)$ ductile cast iron passivated in 100,000 ppm $\mathrm{NaNO}_{2} ;(\mathrm{a})$ and $\left(\mathrm{a}^{\prime}\right) \mathrm{Fe} 2 \mathrm{p},(\mathrm{b})$ and $\left(\mathrm{b}^{\prime}\right) \mathrm{Fe} 2 \mathrm{p}$, and $(\mathrm{c})$ and $\left(\mathrm{c}^{\prime}\right) \mathrm{N} 1 \mathrm{~s}$. 


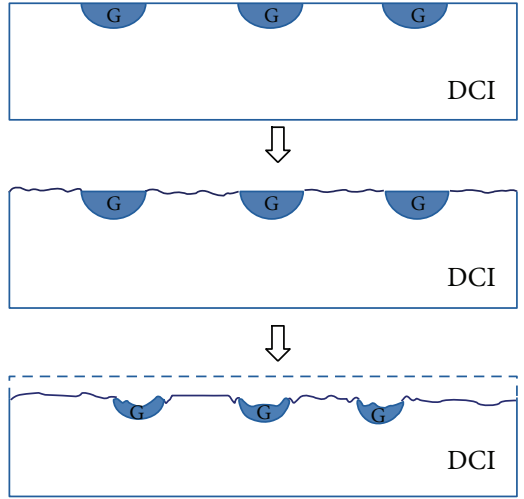

(a)

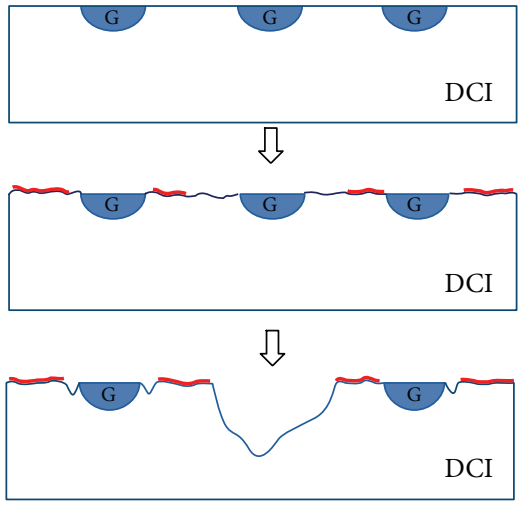

(b)

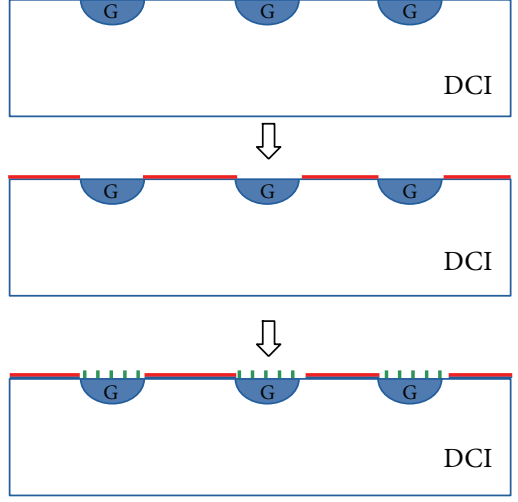

(c)

FIGURE 15: Corrosion and inhibition steps with nitrite addition of ductile cast iron; (a) without corrosion inhibitor, (b) with insufficient corrosion inhibitor $\left(10,000 \mathrm{ppm} \mathrm{NaNO}_{2}\right)$, and with sufficient corrosion inhibitor $(100,000 \mathrm{ppm} \mathrm{NaNO}$ ) $(\mathrm{G}$; graphite, red line; metallic oxide, dot line; nitrogen compound).

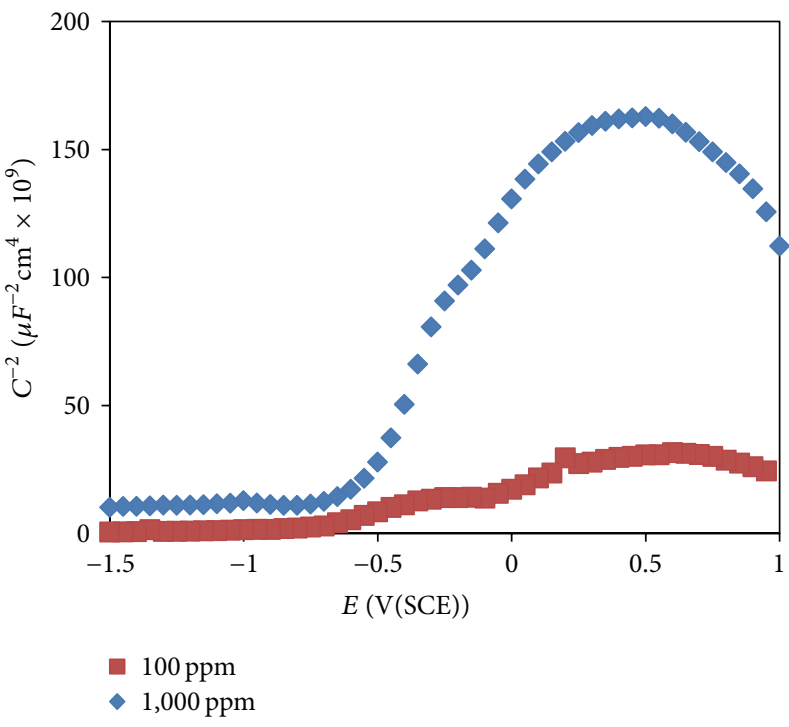

(a)

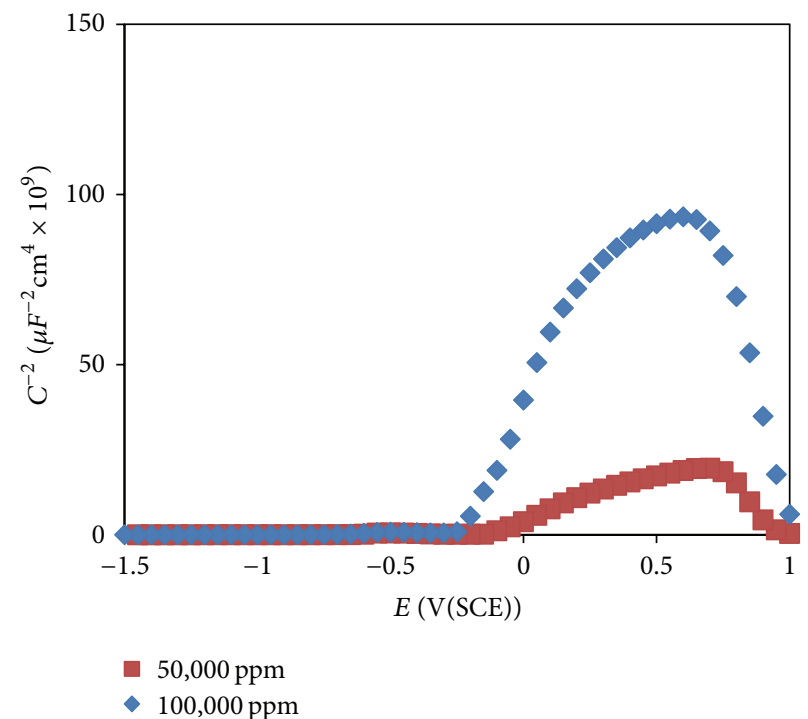

(b)

Figure 16: Effect of $\mathrm{NaNO}_{2}$ addition on Mott-Schottky plot for the passive film formed in deaerated simulated cooling water at $25^{\circ} \mathrm{C}$; (a) carbon steel at $+400 \mathrm{mV}$ (SCE) and (b) ductile cast iron at $0 \mathrm{mV}$ (SCE).

nitrogen compounds could be detected in the EPMA and XPS results. Therefore, since nitrite ion needs to oxidize the surface of the matrix and needs to passivate the galvanic corroded area and since it is absorbed on the surface of graphite, a larger amount of corrosion inhibitor is needed for ductile cast iron than for carbon steel.

On the other hand, passivated film of various alloys exhibits semiconductive properties [28-30]. Acquisition of Mott-Schottky plots is a usual way for semiconductor materials electrochemical characterization. Mott-Schottky plot (inverse square of space charge layer capacitance, $C_{\mathrm{sc}}{ }^{-2}$, versus semiconductor electrode potential $E$ ) gives doping density by slope of the straight line and flat band potential by intercept [31]. A positive slope in the plot indicates the $\mathrm{N}$-type semiconductive properties. Figure 16 shows a Mott-Schottky plot of the effect of $\mathrm{NaNO}_{2}$ addition for the passive film formed in deaerated simulated cooling water at $25^{\circ} \mathrm{C}$. Regardless of the alloys, the increasing inhibitor concentration strengthened the $\mathrm{N}$-type properties. Also these plots revealed the N-type semiconductive properties of the passivated surface film due to nitrite addition.

\section{Conclusions}

(1) While $\mathrm{NaNO}_{2}$ addition can greatly inhibit the corrosion of carbon steel and ductile cast iron, in order to improve the similar corrosion resistance, $c a .100$ times more $\mathrm{NaNO}_{2}$ addition is needed for ductile cast iron than for carbon steel. A corrosion and inhibition mechanism is proposed whereby $\mathrm{NO}_{2}{ }^{-}$ion is added 
to oxidize. The $\mathrm{NO}_{2}{ }^{-}$ion can be reduced to nitrogen compound and this compound may be absorbed on the surface of graphite. Therefore, since nitrite ion needs to oxidize the surface of matrix and needs to passivate the galvanic corroded area and since it is absorbed on the surface of graphite, a greater amount of corrosion inhibitor needs to be added to ductile cast iron than to carbon steel.

(2) The passive film of carbon steel and ductile cast iron, formed by $\mathrm{NaNO}_{2}$ addition, showed N-type semiconductive properties and its resistance is increased; the passive current density is thus decreased and the corrosion rate is then lowered. In addition, the film is mainly composed of iron oxide due to the oxidation by $\mathrm{NO}_{2}{ }^{-}$ion; however, regardless of the alloys, nitrogen compounds (not nitrite) were detected at the outermost surface but were not incorporated in the inner oxide.

\section{Conflict of Interests}

The authors declare that there is no conflict of interests regarding the publication of this paper.

\section{Acknowledgment}

This work was supported by the Nuclear Power Core Technology Development Program of the Korea Institute of Energy Technology Evaluation and Planning (KETEP) granted financial resource from the Ministry of Trade, Industry \& Energy, Republic of Korea (no. 20131520000100).

\section{References}

[1] Plant Shutdown Caused by the Crack of the Essential Service Water System Concrete Pipe, Incident Report 7285: Hanul \#1, Republic of Korea, 1998.

[2] Firewater Supply Valve Downstream Buried Piping Leakage of Intake Area, Equipment Failure Report 06-Hanbit 4-1: Hanbit \#4, Republic of Korea, 2006.

[3] USNRC, “Generic aging lessons learned (GALL) report," Tech. Rep. NUREG-1801, Rev. 2, Division of Regulatory Improvement Programs, 2010.

[4] EPRI, "Nondestructive evaluation; guided wave technology development and nuclear application assessment," Tech. Rep. EPRI-1015156, 2007.

[5] EPRI, "Condition assessment of large-diameter buried piping; phase 2-vehicle design and construction," EPRI 1011829, EPRI, 2005.

[6] NRC Inspection Manual, "Inspection of structures, passive components, and civil engineering features at nuclear power plants," Inspection Procedure 62002, United States Nuclear Regulatory Commission (USNRC), 1996.

[7] E. McCafferty, Introduction to Corrosion Science, Springer, New York, NY, USA, 2009.

[8] V. S. Sastri, Corrosion Inhibitors, Principles and Applications, Wiley, London, UK, 1998.

[9] K. N. Mohana and A. M. Badiea, "Effect of sodium nitrite-borax blend on the corrosion rate of low carbon steel in industrial water medium," Corrosion Science, vol. 50, no. 10, pp. 2939-2947, 2008.

[10] M. Cohen, "Inhibition of steel corrosion by sodium nitrite in water," Journal of the Electrochemical Society, vol. 93, no. 1, pp. 26-39, 1948.

[11] R. Pyke and M. Cohen, "Rate of breakdown and mechanism of nitrite inhibition of steel corrosion," Journal of the Electrochemical Society, vol. 93, no. 3, pp. 63-78, 1948.

[12] M. Cohen, R. Pyke, and P. Marier, "The effect of oxygen on inhibition of corrosion by nitrite," Journal of The Electrochemical Society, vol. 96, no. 4, pp. 254-261, 1949.

[13] S. M. Matsuda and H. H. Uhlig, "Effect of $\mathrm{pH}$, sulfates, and chlorides on behavior of sodium chromate and nitrite as passivators for steel," Journal of the Electrochemical Society, vol. 111, no. 2, pp. 156-161, 1964.

[14] W. D. Robertson, "Molybdate and tungstate as corrosion inhibitors and the mechanism of inhibition," Journal of the Electrochemical Society, vol. 98, no. 3, pp. 94-100, 1951.

[15] M. J. Pryor and M. Cohen, "The inhibition of the corrosion of iron by some anodic inhibitors," Journal of the Electrochemical Society, vol. 100, no. 5, pp. 203-215, 1953.

[16] S. Karim, C. M. Mustafa, Md. Assaduzzaman, and M. Islam, "Effect of nitrite ion on corrosion inhibition of mild steel in simulated cooling water," Chemical Engineering Research Bulletin, vol. 14, pp. 87-91, 2010.

[17] Y. T. Horng and Y. L. Tsai, "An investigation of mild steel with nitrogen-containing inhibitor in hydrochloric acid," Corrosion Science and Technology, vol. 2, no. 5, pp. 233-237, 2003.

[18] L. Abosrra, M. Youseffi, and A. F. Ashour, "Effectiveness of calcium nitrite in retarding corrosion of steel in concrete," International Journal of Concrete Structures and Materials, vol. 5, no. 1, pp. 65-73, 2011.

[19] R. Mehra and A. Soni, "Inhibition of corrosion of mild steel by nitrite, hydrogen phosphate and molybdate ions in aqueous solution of sodium chloride," Indian Journal of Engineering \& Materials Sciences, vol. 9, no. 2, pp. 141-146, 2002.

[20] ASME, ASME Boiler \& Pressure Vessel Section II-Part A, 'Ferrous Materials Specifications (Beginning to SA-450)', ASME, 2011.

[21] Korean Agency for Technology and Standards, KS D4311 Ductile Iron Pipe, Korean Agency for Technology and Standards, Gyeonggi-do, South Korea, 2010.

[22] D. D. Macdonald, "The point defect model for the passive state," Journal of the Electrochemical Society, vol. 139, no. 12, pp. 34343449, 1992.

[23] Y. S. Kim, S. J. Park, and Y. R. Yoo, "Galvanic corrosion behavior between carbon steel bolted GECM(graphite epoxy composite material)/Al plates," Corrosion Science and Technology, vol. 12, no. 1, pp. 19-33, 2013.

[24] P. Q. Dai, Z. R. He, W. Q. Wu, and Z. Y. Mao, "Mechanical behaviour of graphite in fracture of austempered ductile iron," Materials Science and Technology, vol. 18, no. 9, pp. 1052-1056, 2002.

[25] J. R. Davis, ASM Specialty Handbook: Cast Irons, ASM International, Novelty, Ohio, USA, 1996.

[26] C. D. Wagner, W. H. Riggs, L. E. Davis, J. F. Moulder, and G. E. Muilenberg, Handbook of X-Ray Photoelectron Spectroscopy, Perkin-Elmer, 1979.

[27] Y. S. Kim, "Synergistic effect of nitrogen and molybdenum on localized corrosion of stainless steel," Corrosion Science and Technology, vol. 9, no. 1, pp. 20-28, 2010. 
[28] H. J. Jang, "Study on the semiconducting properties of the passive films formed on Ni-Cr alloys in $\mathrm{pH} 8.5$ buffer solution," Journal of Advanced Engineering and Technology, vol. 2, no. 2, pp. 285-289, 2009.

[29] A. Di Paola, "Semiconducting properties of passive films on stainless steels," Electrochimica Acta, vol. 34, no. 2, pp. 203-210, 1989.

[30] C. Sunseri, S. Piazza, and F. Di Quarto, "Photocurrent spectroscopic investigations of passive films on chromium," Journal of the Electrochemical Society, vol. 137, no. 8, pp. 2411-2417, 1990.

[31] A. S. Bondarenko and G. A. Ragoisha, "Variable MottSchottky plots acquisition by potentiodynamic electrochemical impedance spectroscopy," Journal of Solid State Electrochemistry, vol. 9, no. 12, pp. 845-849, 2005. 

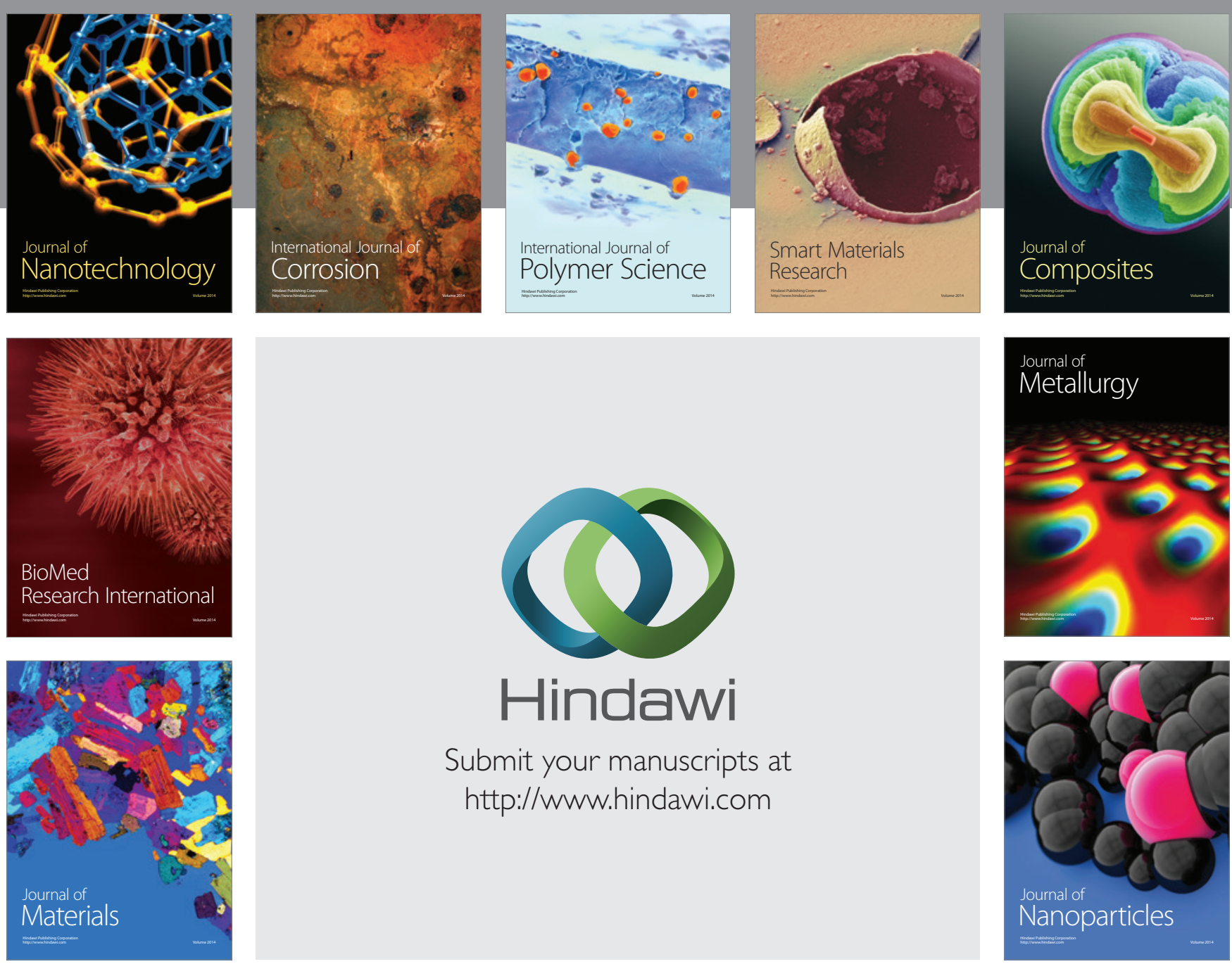

Submit your manuscripts at http://www.hindawi.com
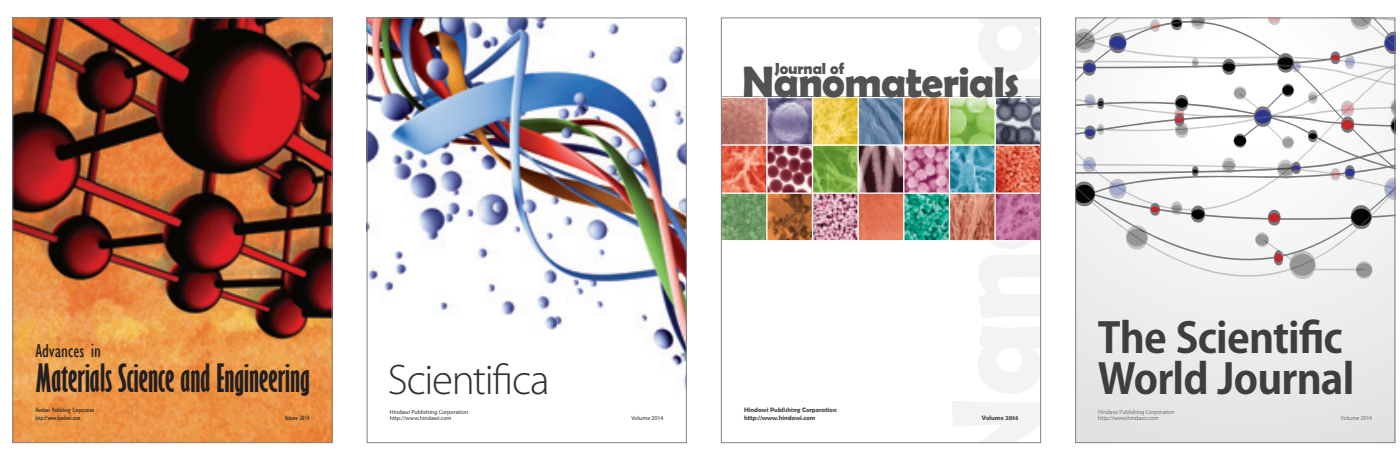

\section{The Scientific World Journal}
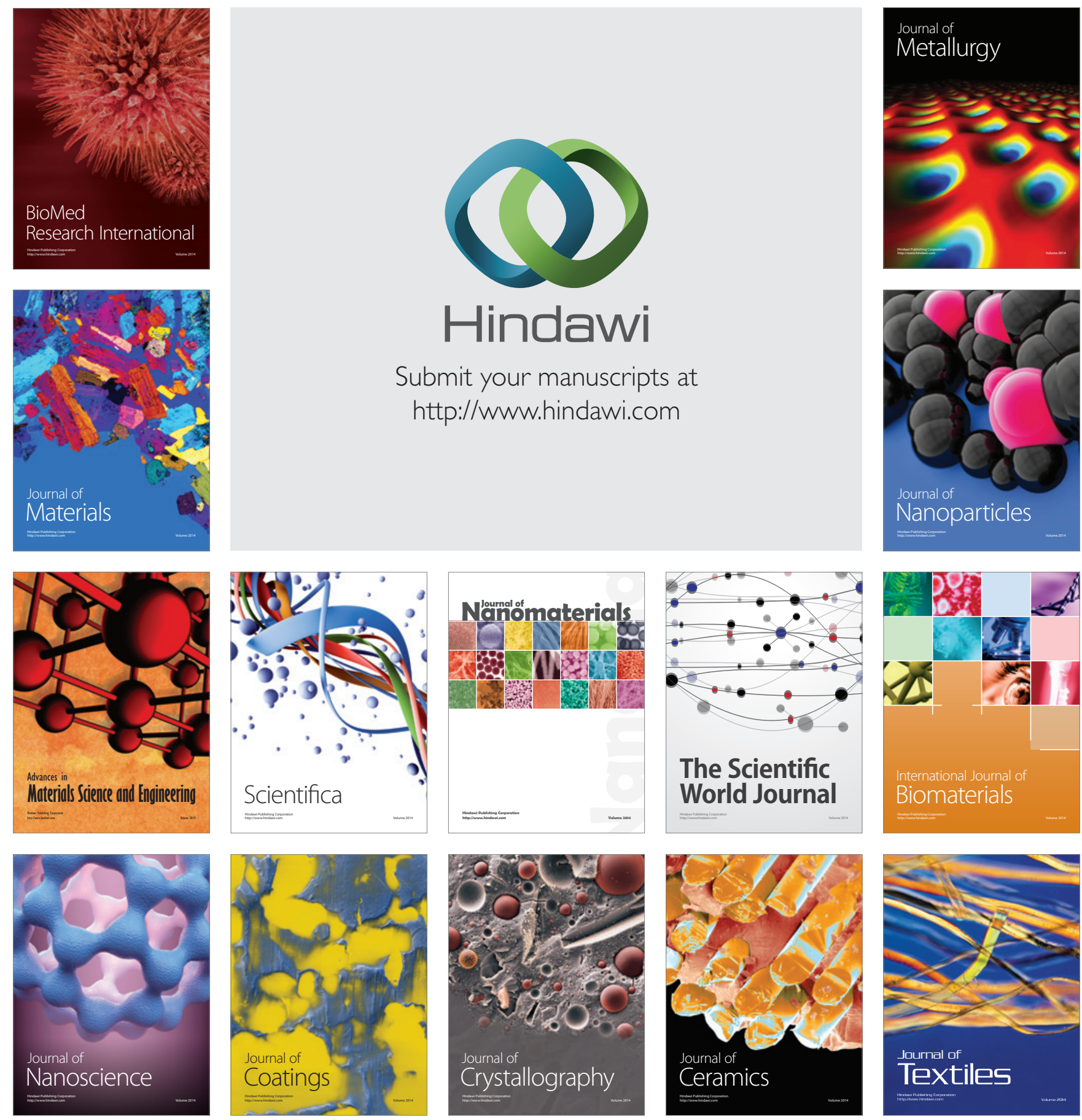